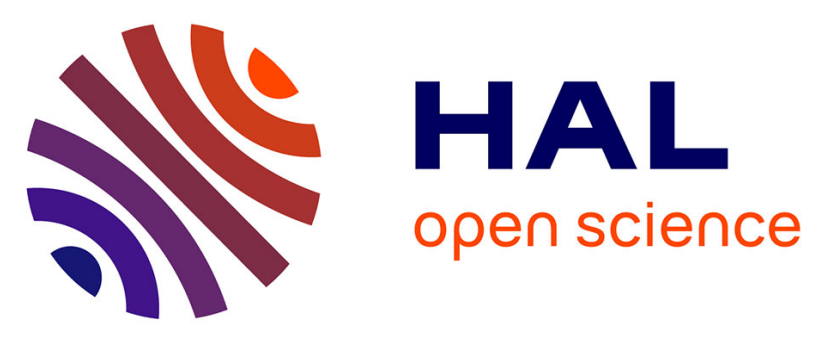

\title{
Determination of regolith production rates from 238U-234U-230Th disequilibrium in deep weathering profiles (Longnan, SE China)
}

Guo-Dong Jia, François Chabaux, Jérôme van Der Woerd, Eric Pelt, Raphaël Di Chiara Roupert, Julien Ackerer, Zhi-Qi Zhao, Ye Yang, Sheng Xu, Cong-Qiang Liu

\section{To cite this version:}

Guo-Dong Jia, François Chabaux, Jérôme van Der Woerd, Eric Pelt, Raphaël Di Chiara Roupert, et al.. Determination of regolith production rates from 238U-234U-230Th disequilibrium in deep weathering profiles (Longnan, SE China). Chemical Geology, 2021, 574, pp.120241. 10.1016/j.chemgeo.2021.120241 . hal-03397087

\section{HAL Id: hal-03397087 https://hal.science/hal-03397087}

Submitted on 9 Nov 2021

HAL is a multi-disciplinary open access archive for the deposit and dissemination of scientific research documents, whether they are published or not. The documents may come from teaching and research institutions in France or abroad, or from public or private research centers.
L'archive ouverte pluridisciplinaire HAL, est destinée au dépôt et à la diffusion de documents scientifiques de niveau recherche, publiés ou non, émanant des établissements d'enseignement et de recherche français ou étrangers, des laboratoires publics ou privés. 
1 Determination of regolith production rates from ${ }^{238} \mathrm{U}^{234} \mathrm{U}-{ }^{230} \mathrm{Th}$ disequilibrium in 2 deep weathering profiles (Longnan, SE China).

3 Guo-Dong Jia ${ }^{1,2}$, François Chabaux ${ }^{2,1}$, Jérôme van der Woerd ${ }^{3}$, Eric Pelt ${ }^{2}$, Raphaël di

4 Chiara $^{2}$, Julien Ackerer ${ }^{2}$, Zhi-Qi Zhao ${ }^{4}$, Ye Yang ${ }^{1}$, Sheng Xu${ }^{1}$, Cong-Qiang Liu ${ }^{1}$

5

6 1- Institute of Surface-Earth System Science, Tianjin University, Tianjin 300072, China

7 2- Laboratoire d'Hydrologie et de Géochimie de Strasbourg (LHyGeS), Université de

8 Strasbourg, CNRS, ENGEES, 1 rue Blessig, 67084 Strasbourg Cedex, France

9 3- Institut de Physique du Globe de Strasbourg (IPGS), UMR 7516, CNRS, Université

10 de Strasbourg, 5 rue René Descartes, 67084 Strasbourg Cedex, France

11 4- School of Earth Science and Resources, Chang'an University, Xi'an 710054, China

Abstract: 390 words

Text: $\approx 7630$ words 


\section{Abstract}

The present study seeks to evaluate the application of the ${ }^{238} \mathrm{U}_{-}{ }^{234} \mathrm{U}_{-}{ }^{230} \mathrm{Th}$ radioactive disequilibrium methodology for the determination of the regolith production rates in thick weathering profiles marked by long histories, encountered under various climate regimes, but still very little studied by these techniques. For this purpose, ${ }^{238} \mathrm{U}-{ }^{234} \mathrm{U}-$ ${ }^{230} \mathrm{Th}$ disequilibria have been analyzed in the top $11 \mathrm{~m}$ of a lateritic profile developed on a granitic bedrock in south China (Longnan, Jiangxi Province) under a subtropical climate. The results demonstrate that in such a weathering profile the determination of weathering rates from the analysis of U-series nuclides in bulk rock samples cannot be recovered by applying in one step to the entire alteration profile the modeling approach classically used to interpret the U-series nuclides, i.e. the "gain and loss" model. The modeling has to be made on subsections of relatively small size $(<1$ or 2 meters of thickness), so that the model assumptions can be met, especially the constancy of the mobility parameters along the weathering zone. The results also confirm that the upper part of the weathering profiles marked by the vegetation/biological influences and responding to the short-term climate variations is not well adapted for applying the Useries nuclides methodology for recovering regolith production rates. Based on the data, regolith production rates were estimated independently on four different deeper zones of the profile. Similar values of $\sim 2 \mathrm{~m} / \mathrm{Ma}$ have been obtained whatever the level, suggesting that such a profile of more than 5 million years would be formed at a relatively stable long-term production rate (averaged over several thousand years). This production rate is slow compared to the production rate deduced from previous in situ ${ }^{10} \mathrm{Be}$ data, which can be explained by assuming non steady-state erosion of the upper part of the profile. Slow denudation rates similar to the U-series derived production rates of $2 \mathrm{~m} / \mathrm{Ma}$ can thus be obtained with a minimum exposure time of $60 \mathrm{ky}$, and an inherited component of 20000 atoms/g originating from the exhumed deeper part of the profile. Altogether the data demonstrate that the combined analysis of U-series and cosmogenic nuclides, which has the potential to become a relevant approach to constrain the dynamics of continental surfaces, requires (a) dense and deep sampling for both nuclides studies, and (b) also to consider more systematically the polyphased 
61 and variable history of erosion of the continental surface during the Quaternary.

62

63

64 


\section{Introduction}

Regolith production and denudation rates are key parameters controlling the response of continental surfaces to environmental modifications, be they anthropic, climatic or tectonic in origin. The knowledge of such time dependent parameters is thus at the heart of numerous present-day scientific issues, for understanding the links between chemical alteration and mechanical erosion processes (e.g., Dixon and von Blanckenburg, 2012), for deciphering the coupling between tectonic exhumation and surface processes of alteration and erosion (e.g., Anderson and Anderson, 2010; Owens and Slaymaker, 2014), or for assessing the role of rock alteration in the carbon cycle and thus in the evolution of earth climate (e.g., Berner and Berner, 1996; Berner and Raiswell, 1983). Addressing these scientific issues rest, partly at least, in our capability to develop geochronological tools for constraining time scales of regolith production and denudation.

Major improvements were achieved since the middle of the $80 \mathrm{~s}$ with the development of terrestrial in-situ cosmonuclide analysis, linked to analytical advances brought by accelerator mass spectrometry (for more details see the review by Granger et al., 2013 and references therein). These tools became in about 30 years major chronometers in geomorphology to quantify denudation rates on the millennial time scale. The application of these techniques enabled real advances in the understanding of the relations between mechanical erosion and chemical alteration of rocks (Dixon and von Blanckenburg, 2012; Riebe et al., 2017). However, interpretations and conclusions often rely on the hypothesis of a steady state functioning of regolith and alteration profile over the millennial time scale. This remains difficult to test without an independent determination of the regolith production rates on similar time scales.

This is possible with the analysis of U-series nuclides, usually ${ }^{238} \mathrm{U}^{234} \mathrm{U}^{230} \mathrm{Th}$, sometimes complemented by ${ }^{226} \mathrm{Ra}$ (e.g., Chabaux et al., 2013 and references therein). This type of analysis was developed from the 1990s, in connection with the development of the precise analyses of the U-series nuclides concentrations by thermoionization mass spectrometry and MC-ICP-MS. U-series nuclide based methods enable to determine the alteration time constants at catchment scale with the analysis of river 
waters and sediments (Dosseto et al., 2006a,b; 2008a; Granet et al., 2007; 2010; Vigier et al., 2001; 2006) as well as at the scale of weathering profiles by the analysis of Useries nuclide concentration variations (Chabaux et al., 2003a,b; 2013; Dequincey et al., 2002; Dosseto et al., 2008b; Ma et al., 2013). The latter approach has been applied to various alteration contexts: centimetric weathering rinds developed on basaltic clasts (Engel et al., 2016; Ma et al., 2012; 2019; Pelt et al., 2008), metric size spheric alteration systems (Chabaux et al., 2013; Claude et al., 2016), decimetric to metric alteration profiles (Ackerer et al., 2016; Dosseto et al., 2008a; Ma et al., 2013; Schoonejans et al., 2016; Rihs et al., 2020). These works have led to the definition of a theoretical and conceptual frame for the application of the radioactive disequilibrium methodology for alteration profiles, which comprises (a) the analysis of the variations of U-series nuclides along the main weathering direction and (b) the interpretation of these variations using a realistic model of radionuclide mobility during water-rock interactions, commonly, a model assuming both gain and loss of elements along the profile (e.g., Chabaux et al., 2008, 2011, 2013; Dosseto et al., 2008b, 2012, 2019; Ma et al., 2013). A key assumption behind this approach is to be able to define, within the studied profile or the alteration system, a sufficiently extended zone for which the mobility parameters may be assumed constant. Usually, the analysis of a few samples (3 to 6 ) in this zone is enough to estimate the nuclide mobility parameters and the sample ages relative to a reference sample (i.e., the deepest one in the profile zone analyzed). The ratio between the thickness and the age of the considered regolith zone gives a mean propagation rate estimate of the alteration front and/or the production rate within the profile, for millennial time scales, which are, as for the cosmonuclides, the time scales accessible by the method.

The recent study performed on the Strengbach catchment site (Ackerer et al., 2016), has clearly highlighted the benefit to combine on the same profile both the insitu cosmonuclide analysis (in this case in situ ${ }^{10} \mathrm{Be}$ in quartz) and the radioactive disequilibria on whole rock. Rates of denudation and regolith production were determined independently establishing firmly the long-term stability of the alteration system. This study demonstrates the importance to carry on these studies using 
radioactive disequilibria as tools to determine regolith production rates, complementary and in parallel to the studies using cosmonuclides. This kind of multidisciplinary approach, combining radioactive disequilibria and cosmonuclides, is certainly one of the present scientific frontiers to explore by the surface science community if one aims at crossing new steps towards understanding the rules that govern continental surfaces functioning (e.g., Riebe et al., 2017).

Such an objective implies to be able to evaluate the applicability of the radioactive disequilibria on thick weathering profiles, not well studied so far, although they are present in a wide range of various climatic settings (tropical equatorial to temperate). As recalled above, the studies of the last 15-20 years have mostly dealt with relatively vertically restricted systems of a few meters maximum. Two exceptions however: the first one is the study on the Kaya lateritic profile, Burkina Fasso (Dequincey et al., 2002; Chabaux et al., 2003b) leading to propose an interpretation scheme of radioactive disequilibria in alteration profiles, which makes the basis for following studies. The ${ }^{238} \mathrm{U}_{-}{ }^{234} \mathrm{U}^{2}{ }^{230} \mathrm{Th}$ disequilibria analyzed in this profile cannot be used in this case to determine the regolith production rate but give information on the $U$ redistribution from the surface to the deeper levels, linked to the upper iron cap destabilization since at least $800 \mathrm{ka}$ (Chabaux et al., 2003a,b). The second one is the study by Dosseto et al. (2012), achieved on a 15 m-deep profile developed on volcanoclastic rocks in Puerto Rico. Unlike the profile of Dequincey et al. (2002), this profile is not a degrading "fossil" profile. The radioactive disequilibria application leads to the estimates of alteration rates, which are larger than rates obtained on a nearby granodiorite profile (Chabaux et al., 2013). These results and their interpretation rest on the strong assumption that the mobility parameters of $U$ and $T h$ are uniform across the whole profile.

The mobility of an element such as $\mathrm{U}$, depends on numerous factors, for instance, the nature of the mineral phases present, the degree of oxidation-reduction of the medium, its $\mathrm{pH}$, the presence of organic and mineral phases that can complex or fix Useries nuclides (e.g., Chabaux et al., 2003a). The diversity of these factors and their probable variation along the weathering profile can obviously make the hypothesis of a constancy of the mobility parameters required by the model difficult to justify over 
an entire several meters thick profile. The study of a granodioritic profile in Puerto Rico (Chabaux et al., 2013) illustrates this point. The profile is marked by a spheroidal alteration, with two contrasted alteration zones: a zone in contact with the bedrock, made of about 20 layers of a few $\mathrm{cm}$ each and a 1 to $2 \mathrm{~m}$-thick zone of unconsolidated laterite, developed towards the surface from these layers. The authors show that the gain and loss model can be applied on each of these two zones, but with different mobility parameters for each of them. Based on this study, along with a few following ones (i.e, Schoonejans et al., 2016; Ackerer et al., 2016; Gonthier et al., 2015), we propose that for several meters thick profiles, often marked by significant mineralogical changes related to the differential weathering of minerals, it is necessary to apply the U-series methodology not to the profile as a whole with a limited number of samples, but on sub-zones of relatively limited thickness within the profile, each ones with a sufficiently dense sampling (3 to 6 samples). We also anticipate that such an approach conducted on different sub-zones of a single weathering profile can be a relevant method for assessing its long-term stability, as the study on the Puerto Rico profile also suggests (Chabaux et al., 2013).

These are the working assumptions that are tested in the present study by analyzing the upper $11 \mathrm{~m}$ of a lateritic profile developed on a granitic bedrock in south China, under a subtropical climate, and already well studied and characterized in term of mineralogy and geochemistry (Cui et al., 2016; Liu et al., 2016; Zhang et al., 2015). In addition, we will compare our results of regolith production rates with the already published denudation rate constrained by in situ ${ }^{10} \mathrm{Be}$ cosmonuclide for this profile (Cui et al., 2016) and discuss the meaning of the observed differences.

\section{Study area and sample selection}

The JLN-S1 profile targeted in this study has been previously analyzed by Zhang et al. (2015), Cui et al. (2016) and Liu et al. (2016). It is located in the northern Nanling granite belt in Longnan, Jiangxi Province, southeastern China (11446'E, $\left.24^{\circ} 58^{\prime} \mathrm{N}\right)$, at an altitude of $225 \mathrm{~m}$ asl (Fig. 1). The study area belongs to a hilly area of moderate relief (altitudes from 600 to $800 \mathrm{~m}$; highest peak at $1200 \mathrm{~m}$ asl $50 \mathrm{~km}$ to the south at 
the sources of the Tao Jiang, a tributary of the Yangtse) in a subtropical zone marked by a humid summer monsoon climate and mostly covered by a subtropical evergreen broadleaf forest. At the study site, the mean annual precipitation (MAP) is $1500 \mathrm{~mm}$ and the mean annual temperature (MAT) is $19^{\circ} \mathrm{C}$, with monthly temperature ranging from $8.3^{\circ} \mathrm{C}$ in January to $27.7^{\circ} \mathrm{C}$ in July (e.g., Schamm et al., 2014). The profile is developed on a K-feldspar granite, formed during the Yanshanian orogeny (end of early Jurassic) and dated at 178.15 $\pm 0.84 \mathrm{Ma}$ (Rb-Sr isochron age; Fan and Chen, 2000). The granite is a medium to coarse-grained granite with porphyritic-like texture. The main phenocrysts are quartz, K-feldspar and plagioclase with small amounts of biotite and hornblende. Magnetite, ilmenite, zircon, fluorite and tourmaline are present as accessory minerals (Chen et al., 2004).

The JLN-S1 profile is exposed in a road cut above the dammed Tao Jiang riverbed (Fig.1). It is located $150 \mathrm{~m}$ away from the summit at the bottom of a ridge with a relatively steep slope (15-18 in Cui et al., 2016). Detailed petrological and mineralogical description can be found in Zhang et al. (2015), Cui et al. (2016) and Liu et al. (2016). In short, the JLN-S1 profile corresponds to the top $11 \mathrm{~m}$ of a granitic weathering profile. Liu et al. (2016) subdivided the JLN-S1 profile into three main horizons, a saprolite horizon from $11 \mathrm{~m}$ to $4 \mathrm{~m}$, a massive soil horizon from $4 \mathrm{~m}$ to $1 \mathrm{~m}$ and a soil horizon $(<1 \mathrm{~m})$ (Fig. 1c). A deeper weathered bedrock horizon is not reached at the JLN-S1 outcrop but deduced from bedrock samples collected close to the bottom of the profile in a nearby streambed. The base of the JLN-S1 profile is assumed to be close to the transition with the deeper weathered bedrock horizon (in Liu et al., 2016). The mineralogy and major element variations allowed the authors to delineate the weathering reaction sequence along the profile (Liu et al., 2016). The weathered bedrock is characterized by dissolution of biotite, hornblende, and apatite. The saprolite horizon is marked by plagioclase dissolution mainly from $11 \mathrm{~m}$ to $\approx 6 \mathrm{~m}$ depth and by kaolinite precipitation all along the horizon. The massive soil horizon is dominated by K-feldspar weathering and also by desilication and conversion of kaolinite into gibbsite. The overlying soil is characterized by primarily dissolved quartz and presence of bioturbation. The depth of $1 \mathrm{~m}$ is also considered by Liu et al. (2016) as the maximum 
depth at which lateral movement of materials moving downslope could be detected. In

addition, the authors have noticed the presence of a quartz vein at a depth of 170-190 $\mathrm{cm}$, and of a vein dominated by plagioclase at a depth of around $700 \mathrm{~cm}$.

For the purpose of our study, it is necessary to define different sub-zones in the profile on which applying independently the U-series methodology. The mineralogical, granulometric and geochemical data show a fairly clear boundary at $4 \mathrm{~m}$ depth between the saprolite horizon and the massive soil horizon defined in Liu et al. (2016) (Fig. 2). In addition, the quartz and plagioclase veins, which crosscut the profile at $2 \mathrm{~m}$ and $7 \mathrm{~m}$ depths, respectively, create two mineralogical discontinuities within the profile, which may impact the assumptions of uniformity of mobility parameters that the model requires. For these reasons, we have subdivided the saprolite into two distinct zones the zone above and below the limit at $7 \mathrm{~m}$ depth. For similar reasons, we have subdivided the upper zone into two subzones, the one below the quartz vein (between $4 \mathrm{~m}$ and $2 \mathrm{~m}$ ) and the one above the quartz vein $(<1.7 \mathrm{~m})$, eventhough it has been shown that the soil horizons are not the best ones to apply the U-series approach (Ackerer et al., 2016; Gontier et al., 2015). We have therefore defined four a priori zones in the profile for applying the U-series methods. They are reported in Fig. 2. In each of these zones, a minimum of 5-6 samples have been selected. The samples are those initially collected for the studies by Zhang et al. (2015) and Liu et al. (2016) following the sampling strategy published in their papers. Mineralogical composition and major element concentrations of most of these samples are given in the above referenced studies.

\section{Analytical and modeling methods}

\subsection{Uranium and thorium analyses}

Uranium and thorium concentrations and isotope ratios were analyzed at the Laboratoire d'Hydrologie et de Géochimie de Strasbourg (LHyGeS), University of Strasbourg and CNRS, France, following a procedure described in Bosia et al. (2018), adapted from previously published ones (Pelt et al., 2013; Granet et al., 2010; Chabaux et al., 1995, 2019). Approximately $100 \mathrm{mg}$ of finely powdered samples were weighted and spiked with a mixed pure artificial ${ }^{233} \mathrm{U}^{229} \mathrm{Th}$ spike and completely digested in low- 
pressure teflon beakers using a multi-step combination of $\mathrm{HF}, \mathrm{HNO}_{3}, \mathrm{HClO}_{4}, \mathrm{HCl}$ and $\mathrm{H}_{3} \mathrm{BO}_{3}$ acids at $100-200^{\circ} \mathrm{C}$. The ${ }^{233} \mathrm{U}_{-}^{229} \mathrm{Th}$ spike was consistently calibrated at a $\sim 5 \%$ o level both via certified NIST gravimetric solutions (SRM3164U and SRM3159Th) and via ATHO rock standard using data from Williams et al. (1992). Uranium and thorium were separated and purified by a multi-step conventional ion exchange chromatography using Biorad AG1x8 200-400 mesh anionic resin. $U$ and Th isotopes were measured on a plasma mass spectrometer (MC-ICP-MS Neptune) by bracketing method respectively against the natural IRMM-184 U and IRMM-035 Th solutions. As in Cogez et al. (2018), the $\left({ }^{234} \mathrm{U}^{238} \mathrm{U}\right)$ activity ratio used for the IRMM-184 standard is the mean TIMS-Triton value measured at the LHyGeS (internal error-weighted mean $0.9698 \pm$ 0.0011, 2SE, $\mathrm{N}=8$ ) instead of the last certified value from Richter et al. (2005) (0.9682 $\pm 0.0006)$. The latter modification yielded better means for the $\left({ }^{234} U{ }^{238} U\right)$ activity ratio measured in the secular-equilibrium HU1 standard solution that was $1.0010 \pm 0.0022$ (2SD, N=21, 50-70 ppb U) during this study. The IRMM-036 Th standard solution was run 4 to 5 times during each of the 4 Neptune Th-sessions yielding a ${ }^{232} \mathrm{Th} /{ }^{230} \mathrm{Th}$ ratio of $326483 \pm 1932(2 \mathrm{SD}, \mathrm{N}=19,40 \mathrm{ppb}$ Th) consistent with values from Sims et al. (2008) and Carpentier et al. (2016).

Powder digestion replicates of samples and BCR-2 rock standard were used to determine the global precision and accuracy of $U$ and Th isotopic measurements. For this study, the average values of U-Th concentrations and $\left({ }^{234} \mathrm{U} /{ }^{238} \mathrm{U}\right)-\left({ }^{230} \mathrm{Th} /{ }^{238} \mathrm{U}\right)$ activity ratios for the BCR-2 rock standard are $1.698 \pm 0.008-5.865 \pm 0.021 \mathrm{ppm}$ and $0.995 \pm 0.004-1.000 \pm 0.012$ ( $2 \mathrm{SE}, \mathrm{N}=4$ ), respectively, consistent with previous values from LHyGeS laboratory and from other laboratories (Rihs et al., 2020; Sims et al., 2008; Matthews et al., 2010) and consistent within 5\%o with secular equilibrium. Procedural blanks starting just before the digestion step range from 13 to $75 \mathrm{pg}$ and 361 to $494 \mathrm{pg}$ for $\mathrm{U}$ and $\mathrm{Th}$, respectively, and are negligible compared to the amount of $\mathrm{U}$ and Th processed.

3.2 Determination of weathering rates and regolith production rates from ${ }^{238} \mathrm{U}$ - 
For the present study, the determination of the weathering and regolith production rates from the analysis of ${ }^{238} \mathrm{U}_{-}{ }^{234} \mathrm{U}_{-}{ }^{230} \mathrm{Th}$ disequilibria in weathering profiles is based on the approach classically used for such a purpose, which has been detailed in several previous studies (e.g., Ackerer et al., 2016; Chabaux et al., 2011, 2013; Dosseto et al., 2008b; Ma et al., 2012, 2013). In such an approach the time variation of radioactive nuclides for a sample in a weathering zone, is described in terms of continuous processes involving, in addition to the radioactive decay laws, loss and gain processes represented by first-order kinetic rate laws for the loss processes and zero-order kinetic rate laws for the gain processes. The loss processes may include many different processes such as mineral dissolution or nuclide desorption from different minerals, and the gain processes atmospheric dust deposition, illuviation processes, sorption and co-precipitation of nuclides on and within different minerals such as Fe-Mn-oxides, clay minerals for instance. For the modeling approaches all the gain (resp. loss) parameters are lumped into only one bulk parameter. The time variation of the ${ }^{238} \mathrm{U}$ ${ }^{234} \mathrm{U}_{-}{ }^{230} \mathrm{Th}$ nuclides concentration is thus described with the three following equations:

$$
\begin{gathered}
\frac{d^{238} U}{d t}=f_{238}{ }^{238} U_{0}-k_{238}{ }^{238} U-\lambda_{238}{ }^{238} U(1) \\
\frac{d^{234} U}{d t}=f_{234}{ }^{234} U_{0}+\lambda_{238}{ }^{238} U-k_{234}{ }^{234} U-\lambda_{234}{ }^{234} U(2) \\
\frac{d^{230} T h}{d t}=f_{230}{ }^{230} T h_{0}+\lambda_{234}{ }^{234} U-k_{230}{ }^{230} T h-\lambda_{230}{ }^{230} T h(3)
\end{gathered}
$$

where $\lambda_{\mathrm{i}}, k_{\mathrm{i}}$ and $f_{\mathrm{i}}$ are the radioactive decay, loss and gain constants (in $\mathrm{yr}^{-1}$ ), respectively, for the radionuclides i (i.e., ${ }^{238} \mathrm{U},{ }^{234} \mathrm{U},{ }^{230} \mathrm{Th}$ ). In the equations, $t$ is the time elapsed between the reference weathering state and its current state. For simplification during the equation-solving procedure, the input fluxes are expressed as a proportion of the number of atoms of nuclides added per year to the initial sample. The loss $(k)$ and gain $(f)$ terms used in the equations are usually assumed to be constant with time (e.g., Chabaux et al., 2013; Dequincey et al., 2002; Dosseto et al., 2008b; Ma et al., 2013). The mean production rate of regolith, $\mathrm{P}$ (in $\mathrm{mm} / \mathrm{kyr}$ ), can be estimated 
through the resolution of the above equation system and the determination of the age $\Delta t$ (in kyr) of a sample relative to a reference sample from deeper in the profile at a distance $\Delta h$ (in $\mathrm{mm}$ ) along the weathering direction. For isovolumetric weathering, $\mathrm{P}$ $(\mathrm{mm} / \mathrm{kyr})$ is given by:

$$
P=\frac{\Delta h}{\Delta t}
$$

The gain and loss coefficients in equations 1 to 4 are usually not known. The ${ }^{238} \mathrm{U}-{ }^{234} \mathrm{U}-$ ${ }^{230} \mathrm{Th}$ analyses yield only two independent data per sample, i.e., the $\left({ }^{234} \mathrm{U} /{ }^{238} \mathrm{U}\right)$, and $\left({ }^{230} \mathrm{Th} /{ }^{234} \mathrm{U}\right)$ ratios. The analysis of only one sample (in addition to a reference sample) is thus not sufficient to determine the weathering production rate $\mathrm{P}$. The mathematical formalism developed to retrieve such time information assumes that the gain and loss coefficients $\left(k_{i}\right.$ and $\left.f_{i}\right)$ of the model can be considered constants, at least for a part of the profile from which several different samples can be collected and analyzed. The measured $\left({ }^{234} \mathrm{U} /{ }^{238} \mathrm{U}\right)$ and $\left({ }^{230} \mathrm{Th} /{ }^{234} \mathrm{U}\right)$ ratios of each sample are used to determine the mobility parameters of the model and the age of different samples relative to the reference sample. The numerical solutions are obtained using a stochastic quantum particle swarm optimization scheme, the principle of which has been detailed in Chabaux et al. $(2012,2013)$ and is summarized in $\S 4-3$. As recalled and illustrated by Ackerer et al. (2016), such modeling approaches only allow for determination of mean long-term values, i.e., averaged over several kyr or tens of kyr, for nuclide gain and loss parameters and for regolith production rates. The approach does not assume constant weathering rates. The ages of each sample as compared to the reference sample are determined independently.

\section{Results}

Uranium and thorium concentrations and $\left({ }^{234} \mathrm{U} /{ }^{238} \mathrm{U}\right),\left({ }^{230} \mathrm{Th} /{ }^{234} \mathrm{U}\right)$ and $\left({ }^{230} \mathrm{Th} /{ }^{232} \mathrm{Th}\right)$ activity ratios in the regolith and soil samples are given in Table 1.

\subsection{U, Th concentrations and activity ratios}

At the profile scale, uranium and thorium concentrations range from 3.2 to $8.6 \mathrm{ppm}$ and 
27.4 to $53.8 \mathrm{ppm}$, respectively. Variations in Th concentrations along the profile do not show any significant increasing or decreasing trend with depth except perhaps in the upper meter of soil. More importantly, the $\mathrm{Th} / \mathrm{Ti}$ ratio is almost not variable in this profile, without showing any systematic variation along the profile, even across each of the different zones. As Ti is considered as an immobile element regarding weathering in the JLN-S1 profile (Liu et al., 2016; Zhang et al., 2015), the fairly constancy of the $\mathrm{Th} / \mathrm{Ti}$ ratio along the profile indicates a relative immobility of Th in the upper $11 \mathrm{~m}$ of this profile (Fig.3c). The U/Th ratios show a higher variability along the profile with the $\mathrm{U} / \mathrm{Th}$ ratio ranging from 0.1 to 0.2 .

It can be observed a slight but systematic decrease of the U/Th ratio from $\sim 400 \mathrm{~cm}$ to the surface, which could indicate $U$ leaching processes affecting the profile, at least in its upper part (Fig. 3d). In the deepest horizons, the U/Th ratio is more variable, especially between $7 \mathrm{~m}$ and $4 \mathrm{~m}$ depth with significant variations over short distances. Without a more detailed mineralogical knowledge of the profile, which is beyond the scope of the study, it is difficult to constrain the origin of such variations. They could indicate differences in some of the mineralogical characteristics of the parent rocks at the origin of these horizons, relative to the other horizons. They could also indicate different and variable $U$ mobilities over short distances in these intermediate and deeper levels. These characteristics are important to keep in mind when discussing the applicability of our approach to these intermediate levels of the profile.

$\left({ }^{234} \mathrm{U} /{ }^{238} \mathrm{U}\right)$ and $\left({ }^{230} \mathrm{Th} /{ }^{234} \mathrm{U}\right)$ activity ratios range from 0.936 to 1.014 and from 0.814 to 1.122 , respectively (Table 1 , Fig. 4). In the deeper part of the profile (deeper than $\sim 800 \mathrm{~cm}$ ) these ratios have rather constant values scattered around 0.94 for $\left({ }^{234} \mathrm{U} /{ }^{238} \mathrm{U}\right)$ and 1.07 for $\left({ }^{230} \mathrm{Th} /{ }^{234} \mathrm{U}\right)$. Above, the $\mathrm{U}$ activity ratio increases to secular equilibrium $\left(\left({ }^{234} \mathrm{U} /{ }^{238} \mathrm{U}\right)=1\right)$ at around $600 \mathrm{~cm}$ depth, then remains close to the equilibrium value. Above $135 \mathrm{~cm},\left({ }^{234} \mathrm{U} /{ }^{238} \mathrm{U}\right)$ is $>1$ and variations are small. For $\left({ }^{230} \mathrm{Th} /{ }^{234} \mathrm{U}\right)$, between $800 \mathrm{~cm}$ and the surface, three zones can be defined. From 800 to $400 \mathrm{~cm},\left({ }^{230} \mathrm{Th} /{ }^{234} \mathrm{U}\right)$ decreases from 1.12 to 0.93 ; then increases to reach 1 at $\approx 150 \mathrm{~cm}$ depth; in the uppermost horizons $(>135 \mathrm{~cm})$, both $\left({ }^{230} \mathrm{Th} /{ }^{234} \mathrm{U}\right)$ and $\left({ }^{234} \mathrm{U} /{ }^{238} \mathrm{U}\right)$ ratios are relatively constant with values greater than 1 . The depth variation of $\left({ }^{230} \mathrm{Th} /{ }^{232} \mathrm{Th}\right)$ 
(Fig. 4) looks like that of $U / T h$ with relatively limited variations $(0.33$ to $\approx 0.4)$ in the deeper $(1100$ to $700 \mathrm{~cm})$ and upper part $(>400 \mathrm{~cm})$ of the profile and a much larger scatter, in the intermediate part of the profile between 700 and $400 \mathrm{~cm}$ depth, where $\left({ }^{230} \mathrm{Th} /{ }^{232} \mathrm{Th}\right)$ ranges from 0.35 to $\approx 0.54$.

\subsection{Modeling results}

As explained in section 2 four a priori zones have been defined in the profile for interpreting the variations of the ${ }^{238} \mathrm{U}_{-}{ }^{234} \mathrm{U}^{230} \mathrm{Th}$ disequilibria within each of these zones using the modeling approach detailed in section 3.2. The small variations of the $\mathrm{Th} / \mathrm{Ti}$ ratios along the profile suggest a low mobility of Th during weathering processes within the profile. For all the simulations, Th has been therefore considered as immobile, which imposes $f_{230}=k_{230}=0$ in the modeling equations. The initial (or a priori) variation ranges for the other model parameters are $10^{3}$ to $10^{6} \mathrm{yr}$ for final age, $10^{-9}$ to $10^{-3} \mathrm{yr}^{-1}$ for $k_{238}$ and $k_{234}$, and $10^{-12}$ to $10^{-5} \mathrm{yr}^{-1}$ for $f_{238}$ and $f_{234}$. In addition, an a priori variation range from 0.5 to 3 has been retained for the two $k_{234} / k_{238}$ and $f_{234} / f_{238}$ ratios.

Using such initial constraints, application of the modeling approach on each of the four initially defined zones shows that only in zone 2 the $\left({ }^{234} \mathrm{U} /{ }^{238} \mathrm{U}\right)$ and $\left({ }^{230} \mathrm{Th} /{ }^{234} \mathrm{U}\right)$ activity variations can be simulated correctly with the same set of parameters for the whole zone (Fig. 5). For the two deeper ones, this was not possible. In the deepest zone, simulations are only feasible by dividing this zone into two new sub-zones (4a-4b) (Fig. 5). The variations of the ${ }^{238} \mathrm{U}_{-}{ }^{234} \mathrm{U}_{-}{ }^{230} \mathrm{Th}$ disequilibria within zone 3 are also impossible to simulate with a single set of parameters all along the zone. For this part of the profile, the model as described by equation 1 can be applied on only a limited thickness of zone 3 , i.e., on the upper part of the plagioclase vein and slightly above (sub-zone 3a, Fig. 5). The uppermost zone of the profile (zone 1 in Fig. 2) is marked by very small variations of $\left({ }^{234} \mathrm{U} /{ }^{238} \mathrm{U}\right)$ and $\left({ }^{230} \mathrm{Th} /{ }^{234} \mathrm{U}\right)$ activity ratios, which prevent any precise simulation. This zone will thus no longer be considered in the following. We will thus model only zone 2 and the 3 sub-zones 3a, 4a and $4 \mathrm{~b}$ (Fig. 5).

For each of these zones the modelling approach has been applied following the procedure described in Chabaux et al. (2013). The unknown parameters, i.e., the $k$ and 
$f$ mobility parameters of ${ }^{238} \mathrm{U}$ and ${ }^{234} \mathrm{U}$ nuclides, and the age of the different samples relative to the reference sample, are determined by a Quantum-behaved Particle Swarm Optimization (QPSO) algorithm (e.g., Sun et al., 2004). It is a population-based evolutionary technique in which each particle or bee is provided with a set of parameters. The technique does not work on individual particles only, but on a set of particles (named swarm) moving in a multidimensional search space. At each time step, the whole swarm is tested against the model. Each particle is used to calculate theoretical activity ratios from the equations 1 to 4 and the theoretical values are compared to the measured ones at the least squares sense, i.e., by calculating the objective function defined as the sum of the squares of the residues between measured and calculated values. The retained simulations are those whose objective function is below a predefined threshold value. In the developed approach, to provide a more comprehensive learning algorithm, particles are allowed to share memories of their best positions in a local neighbourhood. Therefore, an optimal solution emerges from the swarm.

For the first step of the simulation, particles are randomly distributed in the a-priori parameter space, defined from the a priori variation ranges retained for the different model parameters (see above). In order to respect a satisfactory balance between exploration (local minima) and exploitation (best fit) of the solution space, we performed for each modelled zone 10 to 20 independent simulations, leading to 10 to 20 independent minimizations and we retained for each independent simulated swarm the 5000 solutions that fit data under a recruitment criterion initially fixed at $3 \%$ for the objective function. 50,000 to 100,000 admissible solutions are therefore recovered for each modelled zone of the profile. The criterion of 3\% was defined to ensure a satisfying fit with respect to error bars. We have however verified that the results of the simulations do not differ whether we use a threshold of $3 \%$ or $1.5 \%$ for the objective function. This indicates the globally convergent behaviour of the method.

In order to estimate means and standard deviations of simulated values that are statistically meaningful a Kernel Density Estimation (KDE) fitted on a normal distribution was applied to the entire population of the $50,000(100,000)$ solutions 
recovered by the simulation procedure. The values for the production rate, the different mobility parameters as well as of some of their ratios are given in Table 2 for the 4 modelled zones.

The results show that the weathering production rates are of similar magnitude for the 4 modeled zones (Table 2$)$, with values of $\sim 2 \mathrm{~m} / \mathrm{Ma}(1.85 \pm 0.59$ to $2.66 \pm 0.23 \mathrm{~m} / \mathrm{Ma}$ ). The mean values of gain $(f)$ and loss $(k)$ parameters derived from the simulation for $\mathrm{U}$ range from $9.504 \times 10^{-7}$ to $5.249 \times 10^{-6} \mathrm{y}^{-1}$ for $k_{234}$, from $5.645 \times 10^{-7}$ to $3.520 \times 10^{-6} \mathrm{y}^{-1}$ for $k_{238}$, from $8.929 \times 10^{-7}$ to $2.522 \times 10^{-6} \mathrm{y}^{-1}$ for $f_{234}$ and from $6.045 \times 10^{-7}$ to $2.090 \times 10^{-6} \mathrm{y}^{-1}$ for $f_{238}$. They fall into the range of previously published values for shale, granodiorite and granite (Ackerer et al., 2016; Chabaux et al., 2013; Dequincey et al., 2002; Dosseto et al., 2008b; Ma et al., 2013). The values tend to vary along the profile with loss and gain parameters higher and lower, respectively, in the deeper zones than in the upper ones (Table 2). The difference of the mobility coefficients between the zones are, however, much more apparent when compared to the $k_{238} / f_{238}$ and $k_{234} / f_{234}$ ratios (Fig 6), with values systematically higher than 1 in the deeper parts of the profiles (zones $4 \mathrm{a}$ and $4 \mathrm{~b}$ ) and lower than 1 in the upper parts (zones 2 et $3 a)$.

\section{Discussion}

\subsection{Application of the modeling approach}

The results obtained for this study clearly validate our working hypothesis that in such relatively thick weathering profiles the determination of weathering rates from the analysis of U-series nuclides in bulk rock samples cannot be recovered by applying the modeling approach in one step to the entire alteration profile. The modeling has to be made on subsections of relatively small size, so that the model assumptions can be met, especially those concerning the constancy of the mobility parameters along the weathering zone. As highlighted with the above results, the mobility parameters vary along the profile, with significant differences in the massive soil zone (zone 2) and the deep saprolite zone (zones $4 \mathrm{a}, 4 \mathrm{~b}$ ) for both $\mathrm{U}$ gain and loss parameters, which result in systematic differences in the $k / f$ ratios between the upper and deeper zones (Fig. 6). Liu et al. (2016) have characterized the sequence of weathering and transformation of main 
major minerals in the JLN-S1 profile. The resulting differential weathering sequence lead to mineralogical zonation along the profile, which might be invoked to partly explain the observed mobility parameter variations. Thus, the higher $U$ loss coefficients in zones $4 \mathrm{a}$ and $4 \mathrm{~b}$ than in the massive soil (zone 2 ) and in zone $3 \mathrm{a}$, could result from a relatively larger dissolution of primary minerals in the JLN-S1 deep level (Liu et al., 2016), compared to the upper levels, as illustrated for example by the plagioclase variation curve given in Fig. 2. Similarly, the larger U gain parameters in the shallower zones 2 and $3 \mathrm{a}$ than in the deeper ones, might explain the gibbsite precipitation in the upper part of the profile (Liu et al., 2016), which can significantly adsorb U.

The modeling results support also the conclusions of previous works (Ackerer et al., 2016; Gontier et al., 2015; Rihs et al., 2016) that the upper part of the weathering profiles marked by the vegetation/biological influences is not well adapted for applying the U-series nuclides methodology for recovering regolith production rates. More importantly, they also indicate that below the vegetation influence zone, the zones suitable for application of the modeling approach do not exceed 1 or 2 meters in thickness, and that all parts of the profile are not necessarily appropriate for such modeling. This is certainly related to the spatial variability of the parameters controlling the mobility of an element such as $U$ in a weathering profile. In addition to the physical and chemical parameters of the medium $(\mathrm{pH}, \mathrm{Eh})$, which can indeed vary over short distances, metric or less, the nature of the mineral phases present and their spatial variability are also important to consider. In a weathering profile, these mineral phases control the capacity of $U$ to be released by dissolution of the $U$-carrier phases or to be fixed on secondary mineral phases. In the JLN-S1 profile, the differential weathering processes as well as the initial lithological heterogeneity, which both may cause mineral paragenesis variations over quite short distances, may be invoked to explain the low vertical extension of the zones to which the proposed model for interpreting U-Th disequilibria variations can be applied. For instance, in zone 4, the deepest part (4b) is marked by a rather significant variation of plagioclase proportions with depth, while in the overlying zone (4a) the plagioclase content is fairly constant. Such differences certainly indicate weathering processes or even differential weathering sequences, 
significantly different between these two zones, which can easily explain why simulation of ${ }^{238} \mathrm{U}_{-}{ }^{234} \mathrm{U}_{-}{ }^{230} \mathrm{Th}$ disequilibria variations along zone 4 must be done on the two subzones with two different sets of mobility parameters. In addition, zone 3 is marked by a strong lithological heterogeneity due to the presence of a plagioclase vein. The mineralogical variations that such a vein induce may result in a significant variation of the mobility parameters across zone 3 , which is too strong compared to the number of analyzed samples for allowing the application of the modeling approach in this zone, outside the subzone 3a. These different results thus clearly evidence that in thick weathering profiles the degree of mineralogical variability along the profile can become a critical not to say a limiting factor for the applicability of the methodology of $U$-series disequilibrium on bulk rock samples to recover regolith production rates. The above approach at least for profiles developed on granitic bedrock can therefore only be applied to sections of relatively limited vertical extension. As a consequence, the profile parts over which the simulations can be performed, at least in the case of the Longnan profile, are narrow layers where the variations in $\left({ }^{234} \mathrm{U} /{ }^{238} \mathrm{U}\right)$ and $\left({ }^{230} \mathrm{Th} /{ }^{234} \mathrm{U}\right)$ ratios are relatively small compared to the analytical uncertainties. This explains why a very large number of simulations can fit the data and therefore why the alteration rates and mobility parameters obtained by this approach cover a wide range of possible values. Although more constraints can be considered by perhaps increasing the number of samples per sub-area (e.g., in subzones $4 \mathrm{a}$ or $4 \mathrm{~b}$ ) this intrinsic characteristic of the data will not be modified and the application of this approach at least in this study case will mainly give orders of magnitude for the model parameters. Nevertheless, as detailed in the following section, these orders of magnitude are sufficient to discuss the relationships between the regolith denudation and production rates.

\subsection{Comparison of long-term regolith production and denudation rates}

As presented in the results section, a weathering front propagation rate can be determined in four different zones $(2,3 \mathrm{a}, 4 \mathrm{a}, 4 \mathrm{~b})$, leading to the determination of four different rates, but of the same order of magnitude, with values of $\sim 2 \mathrm{~m} / \mathrm{Ma}$. Such an observation implies that weathering in the JLN-S1 profile propagates at similar rates 
along the studied zone, i.e., from $10 \mathrm{~m}$ depth, bottom of zone $4 \mathrm{~b}$ to $2 \mathrm{~m}$ depth, summit of zone 2, and that a sample moves up from the bottom of this $8 \mathrm{~m}$-thick zone to its summit in about 4 million years. If we admit that this rate is about the same on the whole profile outcrop and by assuming, as explained in Liu et al. (2016), that the bedrock-saprolite transition zone is close to the outcrop base, the $11 \mathrm{~m}$-thick profile may reach a minimum age of 5.5 million years near its top. The feasible simulations on this profile were applied on sections of small vertical extension, usually $\leq 1 \mathrm{~m}$, which correspond to durations of about $500 \mathrm{ky}$, while the sample vertical thickness of about 20 to $50 \mathrm{~cm}$ represents an average time window of 100 to $250 \mathrm{ky}$. Such a loose time resolution, associated with the large uncertainty on the rate determination, makes it difficult to accurately evaluate by this approach the impact of environmental processes varying over shorter time scales, such as the quaternary climate fluctuations (10-20 ka, e.g., Lisiecki and Raymo, 2005), or the anthropogenic activity ( $<10 \mathrm{ka})$, on the weathering rates. On the other hand, the similarity of weathering rates obtained in the present study from the bottom of the profile to about $2 \mathrm{~m}$ depth implies that the average long-term millennial rates did not vary a lot over the last 4 million years, at least in the deeper part of the profile. In other words, this means that on such long-time scales and in its deeper part the weathering profile is close to "steady state". At first order, this is consistent with the fact that the geographical area is tectonically stable since the end of the Paleogene ( $\approx 23$ Ma; e.g., Faure et al., 2017), and that the modern climatic pattern, controlled by the East Asian monsoon, was established since at least the MiocenePliocene transition $5 \mathrm{Ma}$ ago, with alternations of wet and dry periods during the Pleistocene and a currently subtropical climate since $\approx 10 \mathrm{ka}$ (e.g., Wang et al., 2016).

As recalled in $\$ 3.2$, for an isovolumic weathering at steady-state the weathering rate determined by the radioactive disequilibrium methodology corresponds directly to the regolith formation rate. For the studied profile, the isovolumic character has been validated for most of the first $4 \mathrm{~m}$, notably in the massive soil unit (zone 2 in our study) in Cui et al. (2016). It is thus tempting to extend this result to the rest of the profile and to assume isovolumic weathering in the underlying more compact rocks. With this assumption and on the basis of our estimates, a long-term regolith production rate of 
$\approx 2 \mathrm{~m} /$ Ma can thus be proposed for the weathering profile for the last 4-5 million years determined at best with a resolution of a few 10 kyrs.

Such a result indicates therefore that the regolith production rate calculated in the present study with U-series nuclides on the deeper part of the JLN-S1 profile is about 10 times slower than the denudation rate estimated on the upper part of the same profile by Cui et al. (2016) using in-situ produced cosmogenic nuclides. More precisely, the denudation rate was determined from 6 samples collected along the uppermost $4 \mathrm{~m}$ of the JLN-S1 profile by interpreting the depth variations of the in situ ${ }^{10} \mathrm{Be}$ concentrations with the usual depth profile equation (eq. 1 and 2 in Cui et al., 2016) assuming steadystate. The authors also considered, as classically done in many previous studies (e.g., Brown et al., 1995; Granger and Smith, 2000; Braucher et al., 2009), that bedrock alteration profiles do not bear inheritance prior exposure. Such assumptions result in a modeled denudation rate of $17.7 \pm 0.5 \mathrm{~m} / \mathrm{Ma}$ and a minimum exposure time of $349 \pm$ $26 \mathrm{ka}$ (Fig. 7a; modeling following Yang et al., 2019, 2020), values very similar to 19 $\pm 3 \mathrm{~m} / \mathrm{Ma}$ and $\approx 300 \mathrm{ka}$ in Cui et al. (2016). The JLN-S1 profile would thus be characterized by an important discrepancy between the regolith production rate determined on the lower part of the profile and its denudation rate estimated on its upper part. Such differences would no more allow this profile to be considered as being at steady state: the thickness of the weathering profile would decrease with time and the $10 \mathrm{~m}$ thick profile would disappear in about $600 \mathrm{ky}$.

However, with a similarly precise fit to the ${ }^{10} \mathrm{Be}$ data (Fig. 7a), but accounting for inheritance (e.g., Ackerer et al., 2016; Yang et al., 2020), a slower denudation rate similar to the U-series derived production rates of about $2 \mathrm{~m} / \mathrm{Ma}$ is obtained with a minimum exposure age of $60 \mathrm{ky}$ (best estimate 60-76ka) and considering an inherited concentration of ${ }^{10} \mathrm{Be}$ of $16-21 * 10^{3}$ atoms $/ \mathrm{g}$. Such inheritance is in this case not due to prior near surface exposure, but to ${ }^{10} \mathrm{Be}$ accumulation from muonic production at great depth over long periods. Such a model implies that the profile has suffered stripping of its top layers (about at least $1 \mathrm{~m}$ ) during a short period $\approx 60 \mathrm{ky}$ ago and that since that time it is characterized by a relatively slow denudation rate $(\leq 2 \mathrm{~m} / \mathrm{Ma})$.

Based on the above interpretation that reconciles the ${ }^{238} \mathrm{U}_{-}{ }^{234} \mathrm{U}_{-}{ }^{230} \mathrm{Th}$ disequilibria 
and in situ ${ }^{10} \mathrm{Be}$ data, we propose that the profile has reached a relatively long-term stability, over the last few millions of years, with long term denudation and production rates of $\approx 2 \mathrm{~m} / \mathrm{Ma}$, episodically interspersed with fast and short intense denudation periods (Fig. 8). This scenario is similar to the interpretation proposed by Ackerer et al. (2016) from the combined analysis of U-Th-Ra disequilibrium and in situ ${ }^{10} \mathrm{Be}$ concentration in a $2 \mathrm{~m}$-deep weathering profile sampled at the summit of the granitic Strengbach catchment (Vosges mountain, France). The authors show that the ${ }^{10} \mathrm{Be}$ concentration variation with depth implies similar denudation and production rates for the regolith, with an exposure age of about $20 \mathrm{ka}$ and an average inheritance in agreement with a short period of erosion of the upper part (2-4 m) of the profile about $20 \mathrm{ka}$ ago, linked to the climatic variation in this mountainous region in Europe, in particular the last glacial maximum. The JLN-S1 profile, is located in a tropical climate, where glacial or peri-glacial processes cannot be responsible for the change in erosional processes. We thus make the assumptions that the production and denudation rates of about $2 \mathrm{~m} / \mathrm{Ma}$ correspond to an average long-term rate, resulting from long phases of low erosion, similar to present-day conditions with abundant vegetation cover under a warm and humid climate, and short phases of stronger erosion, when the climate changes are sufficient to significantly impact the density of the vegetation cover, probably during dry periods due to monsoon weakening. The return periods of these intense erosional events might be linked to the intensity of the regional changes of the vegetation cover and/or the regional climatic conditions induced by the global climate cycles of the Quaternary (Fig. 8).

Validating this interpretation, however, will certainly need more appropriate sampling of the profile (e.g., Ackerer et al., 2016), namely in its lower part, to better constrain the average inheritance and the ${ }^{10} \mathrm{Be}$ muonic production at great depth (e.g., Heisinger et al., 2002a,b; Braucher et al., 2013; Lupker et al., 2015), but also in its upper part to better assess the recent erosion and denudation, and the near-surface perturbation of the soil layers as possibly reflected in the ${ }^{10} \mathrm{Be}$ concentration scatter of the data (see for instance, figure 3 in Cui et al., 2016). This is clearly outside the scope of this study focused on the analysis of U-series nuclides to determine regolith 
production rates. The important point to be stressed at this stage is (1) that the ${ }^{10} \mathrm{Be}$ data is not necessarily in contradiction with a long-term steady-state functioning of the studied profile, and (2) that the analysis of U-series disequilibria in the "deep" levels of weathering profiles, i.e. below the horizons strongly influenced by erosion processes, is certainly well adapted to determine long-term regolith production rates. The JLN-S1 results also emphasize that the future development of the combined analyses of U-series and cosmogenic nuclides, which are important to constrain the long-term dynamics of continental surfaces, requires dense samplings with depth for both nuclides studies, certainly denser than what has been usually performed to date. They also indicate that the correct interpretation the ${ }^{10} \mathrm{Be}$ data in such granitic context requires to consider more systematically the importance of muonic accumulation of ${ }^{10} \mathrm{Be}$ at depth, in relation to the polyphased history of erosion of the continental surfaces during the Quaternary.

\section{Conclusions}

The analysis of ${ }^{238} \mathrm{U}_{-}{ }^{234} \mathrm{U}^{230} \mathrm{Th}$ disequilibria in $\mathrm{a} \approx 11 \mathrm{~m}$-deep weathering profile developed on a granitic bedrock in south China (Longnan, Jiangxi Province) allow us to discuss the application of the radioactive disequilibria methodology for determining regolith production rate to thick weathering profiles. The results clearly evidence that for such deep weathering profiles the determination of regolith production rates from the analysis of U-series nuclides in bulk rock samples cannot be recovered with a single interpretative model of the entire alteration profile by the modeling approach classically used to interpret the U-series nuclides variation along a profile, i.e., the "gain and loss" model. The approach must be applied to subsections of relatively small size $(<1$ or $2 \mathrm{~m}$ of thickness), so that the model assumptions can be met, especially those concerning the constancy of the mobility parameters along the weathering zone. The results also confirm that the upper part of the weathering profile, influenced by surface/vegetation/biological processes, is not well adapted for applying the U-series nuclides methodology for recovering regolith production rates. Furthermore, they indicate that in the deeper parts of the weathering profile, all parts of the profile are not necessarily appropriate for the application of the modeling approach, especially in the 
zones marked by short distance variations of mineral paragenesis.

As illustrated with the current study of the Longnan weathering profile, independent determinations of the regolith production rates on different subzones of the weathering profile proves to be a relevant approach to assess the long-term stability of the regolith production. Thus, for the Longnan profile, the observation of similar values of $\sim 2 \mathrm{~m} / \mathrm{Ma}$ in each of the four sub-zones where the regolith production rate has been independently determined, suggests that such a profile of more than 5 million years has been formed at a relatively stable long-term production rate. Such a stable and slow regolith production rate of $2 \mathrm{~m} / \mathrm{Ma}$ at depth can be reconciled with the previously published in situ ${ }^{10} \mathrm{Be}$ data from the upper part of the same profile, when assuming no steady-state erosion of the upper part of the profile. In this case, the ${ }^{10} \mathrm{Be}$ concentrations near the top of the profile result from both a recent stabilization during $60 \mathrm{ky}$ at least and an inherited component of $20 * 10^{3}$ atoms $/ g$ accumulated at great depth. Accumulation of ${ }^{10} \mathrm{Be}$ at depth is due to muonic production during long stable periods of time and brought near the surface due to exhumation of the deeper part of the profile as a result of short periodic intense erosional events.

Altogether our study demonstrates that the combined analysis of U-series and cosmogenic nuclides, which has the potential to become a relevant approach to constrain the dynamics of continental surfaces, requires (a) dense and deep sampling for both nuclides studies, and (b) also to consider more systematically the polyphased history of erosion of the continental surface during the Quaternary, i.e. the long-term accumulation of ${ }^{10} \mathrm{Be}$ at depth due to muonic production.

\section{Acknowledgements}

The authors thank editor Balz Kamber, and reviewer Heather Handley for their very constructive comments, which help us to significantly improve a previous version of the manuscript. The latter also benefited from an anonymous review. The study was financially supported by The National Natural Science Foundation of China (Nos. 41661144042, 41673124, 41603018 and 41930863), the Second Tibetan Plateau Scientific Expedition and Research (2019QZKK0707), the 2018-2019 INSU-CNRS SYSTER Program, France and the Scientific Programs of the LhyGeS-University of Strasbourg, France. 
Table captions:

Table 1: $\mathrm{U}$, Th concentrations and $\left({ }^{234} \mathrm{U} /{ }^{238} \mathrm{U}\right),\left({ }^{230} \mathrm{Th} /{ }^{234} \mathrm{U}\right),\left({ }^{230} \mathrm{Th} /{ }^{232} \mathrm{Th}\right)$ activity ratios

Table 2: Production rates and mobility parameters (ki, fi) obtained for zones 2, 3a, 4a, and $4 \mathrm{~b}$ (see text for details).

\section{Figure captions:}

Figure 1: A) Location of study site in southeast China on mean annual precipitation map of Asia for period 1961-1990 (Schamm et al., 2014; http://gpcc.dwd.de). Arrows are main moisture sources. B) Location of weathering profile (red dot) near Taojiang river left bank north of Longnan city (image background from Google Earth). C) Field view of soil profile outcrop at bottom of forested ridge, people for scale. Inset shows numbered positions of samples. Sample thickness is 10, 20 and $50 \mathrm{~cm}$ between $0-1,1$ 8 , and below $8 \mathrm{~m}$, respectively.

Figure 2: Depth variation of K-feldspar and plagioclase abundances along weathering profile, together with chemical index of alteration (CIA), K/Ti, and grain size (data from Zhang et al. (2015) and Liu et al. (2016)). Samples analyzed in this study and in different zones are shown on schematic column to right, with quartz and plagioclase veins depth indicated. Grey boxes are sample position, black squares are previously analyzed and published samples (Zhang et al., 2015; Liu et al., 2016).

Figure 3: Variations of $U$ (ppm), Th (ppm), U/Th (ppm/ppm) and Th/Ti (ppm/ppm) with depth with location of modeling zones. Error bars are $2 \%, 1.3 \%,<1.6 \%,<5.5 \%$ from left to right. U-Th Data in Table 1, Ti data from Zhang et al. (2015).

Figure 4: Depth variations of $\left({ }^{234} \mathrm{U} /{ }^{238} \mathrm{U}\right),\left({ }^{230} \mathrm{Th} /{ }^{234} \mathrm{U}\right)$ and $\left({ }^{230} \mathrm{Th} /{ }^{232} \mathrm{Th}\right)$ ratios with location of modeling zones. For uncertainties see Table 1.

Figure 5: $\left({ }^{230} \mathrm{Th} /{ }^{234} \mathrm{U}\right)$ vs $\left({ }^{234} \mathrm{U} /{ }^{238} \mathrm{U}\right)$ diagram for zones 2 , 3a, 4a, and $4 \mathrm{~b}$. Grey curve is best-fit calculated with model described in text for each zone. Sample ages are relative to deepest sample in each zone.

Figure 6: gain $\left(k_{i}\right)$ and loss $\left(f_{i}\right)$ coefficient ratios, $\mathrm{k}_{234} / \mathrm{f}_{234}$ as a function of $\mathrm{k}_{238} / \mathrm{f}_{238}$ for model results of zones $2,3 \mathrm{a}, 4 \mathrm{a}$ and $4 \mathrm{~b}$. Inset is zoom for ratios below 1

Figure 7: A) In situ ${ }^{10} \mathrm{Be}$ concentration in quartz (red cross; data in Cui et al., 2016) and modeled exponential decrease with depth. green and blue lines are modeling following Yang et al. (2019), blue assumes steady-state and no inheritance, green with inheritance. Local ${ }^{10} \mathrm{Be}$ spallogenic production rate of 3.74 atoms/g/yr from CRONUS online calculator (Marrero et al., 2016). Slow and fast muons production rate of 0.1066 and 0.0485 atoms $/ \mathrm{g} / \mathrm{yr}$, respectively (Yang et al., 2019). B) Grey boxes (below $2 \mathrm{~m}$ depth) are U-series regolith production rates, green and blue boxes (from surface to $4 \mathrm{~m}$ depth) are ${ }^{10} \mathrm{Be}$ denudation rates with inheritance and without inheritance, respectively (see 
text for details).

Figure 8: Long term evolution of a weathering profile modulated by high and low frequency climate changes as depicted with benthic oxygen isotope curve over $800 \mathrm{ka}$ (top) and 5.5 Ma (bottom), respectively (Lisiecki and Raymo, 2005). $\mathrm{E}_{1}$ and $\mathrm{E}_{2}$ are longand short-term surface denudation rates. $\mathrm{P}$ is steady-state production rate of regolith at depth. Profile evolution steps as follows: 1: Steady state; 2: Fast erosion over a short period; 3: Return to steady state; 4: Steady state.

\section{References:}

Ackerer, J., Chabaux, F., Van der Woerd, J., Viville, D., Pelt, E., Kali, E., Lerouge, C., Ackerer, P., di Chiara Roupert, R., Négrel, P., 2016. Regolith evolution on the millennial timescale from combined $\mathrm{U}-\mathrm{Th}-\mathrm{Ra}$ isotopes and in situ cosmogenic $10 \mathrm{Be}$ analysis in a weathering profile (Strengbach catchment, France). Earth and Planetary Science Letters 453, 33-43.

Akovali, Y.A., 1994. Nuclear Data Sheets for A = 234. Nuclear Data Sheets, 71(1): 181-259.

Anderson, R.S., Anderson, S.P., 2010. Geomorphology: the mechanics and chemistry of landscapes. Cambridge University Press.

Berner, E.K., Berner, R.A., 1996. Global environment water, air, and geochemical cycles Prentice-Hall. Englewood Cliffs, NewJersey.

Berner, R.A., Raiswell, R., 1983. Burial of organic carbon and pyrite sulfur in sediments over Phanerozoic time: a new theory. Geochimica et Cosmochimica Acta 47, 855-862.

Braucher, R., Del Castillo, P., Siame, L., Hidy, A.J., Bourlès, D.L., 2009. Determination of both exposure time and denudation rate from an in situ- produced ${ }^{10} \mathrm{Be}$ depth profile: A mathematical proof of uniqueness. Model sensitivity and applications to natural cases. Quat. Geochronol. 4, 56-67.

Braucher, R., Bourles, D., Merchel, S., Vidani Romani, J., Fernadez-Mosquera, D., Marti, K., Leanni, L., Chauvet, F., Arnold, M., Aumaitre, G., \& Keddadouche, K., 2013. Determination of muon attenuation lengths in depth profiles from in situ produced cosmogenic nuclides. Nuclear Instruments \& Methods in Physics Research Section B - Beam Interactions with Materials and Atoms, 294 , 484-490.

Bosia, C., Chabaux, F., Pelt, E., Cogez, A., Stille, P., Deloule, E., France-Lanord, C., 2018. U-series disequilibria in minerals from Gandak River sediments (Himalaya). Chemical Geology 477, 22-34.

Brown E, Stallard R, Larsen M, Raisbeck G, Yiou F. 1995. Denudation rates determined from the accumulation of in situ-produced ${ }^{10} \mathrm{Be}$ in the luquillo experimental forest, Puerto Rico. Earth Planet. Sci. Lett.129: 193-202, doi: 10.1016/0012-821X(94)00249-X.

Carpentier, M., Gannoun, A., Pin, C., Sigmarsson, O., 2016. New thorium isotope ratio measurements in silicate reference materials: A-THO, AGV-2, BCR-2, BE-N, BHVO-2 and BIR-1. Geostand. Geoanal. Res. 40, 239-256.

Chabaux, F., Cohen, A.S., O'Nions, R.K., Hein, J.H., 1995. ${ }^{238} \mathrm{U}^{2}{ }^{234} \mathrm{U}^{230}$ Th chronometry of Fe-Mn crusts : Growth processes and recovery of thorium isotopic ratios of seawater. Geochim. Cosmoch. Acta 59, 633-638.

Chabaux, F., Riotte, J., Dequincey, O., 2003a. U-Th-Ra fractionation during weathering and river transport. Reviews in Mineralogy and Geochemistry, 52. 533-576.

Chabaux, F., Bourdon, B., Riotte, J., 2008. Chapter 3 U-Series Geochemistry in Weathering Profiles, River Waters and Lakes, in: Krishnaswami, S., Cochran, J.K. (Eds.), Radioactivity in the 
Environment. Elsevier, pp. 49-104.

Chabaux, F., Dequincey, O., Lévèque, J.-J., Leprun, J.-C., Clauer, N., Riotte, J., Paquet, H., 2003 b. Tracing and dating recent chemical transfers in weathering profiles by trace-element geochemistry and ${ }^{238} \mathrm{U}^{234} \mathrm{U}^{230} \mathrm{Th}$ disequilibria: the example of the Kaya lateritic toposequence (Burkina-Faso). Comptes Rendus Geoscience 335, 1219-1231.

Chabaux, F., Ma, L., Stille, P., Pelt, E., Granet, M., Lemarchand, D., Roupert, R.d.C., Brantley, S.L., 2011. Determination of chemical weathering rates from $U$ series nuclides in soils and weathering profiles: Principles, applications and limitations. Applied Geochemistry 26, S20-S23.

Chabaux, F., Blaes, E., Granet, M., Roupert, R.d.C., Stille, P., 2012. Determination of transfer time for sediments in alluvial plains using ${ }^{238} \mathrm{U}_{-}{ }^{234} \mathrm{U}^{230} \mathrm{Th}$ disequilibria: The case of the Ganges river system. Comptes Rendus Geoscience 344, 688-703.

Chabaux, F., Blaes, E., Stille, P., di Chiara Roupert, R., Pelt, E., Dosseto, A., Ma, L., Buss, H.L., Brantley, S.L., 2013. Regolith formation rate from U-series nuclides: Implications from the study of a spheroidal weathering profile in the Rio Icacos watershed (Puerto Rico). Geochimica et Cosmochimica Acta 100, 73-95.

Chabaux F., Stille P., Prunier J., Gangloff S., Lemarchand D., Morvan G., Négrel J., Pelt E., Pierret M.C., Rihs S., Schmitt A.D., TrémolièresT., Viville D., 2019. Plant-soil-water interactions: Implications from U-Th-Ra isotope analysis in soils, soil solutions and vegetation (Strengbach CZO, France). Geochimica et Cosmochimica Acta 259 188-210.

Chen, P.R., Zhou, X.M., Zhang, W.L., Li, H.M., Fan, C.F., Sun, T., Chen, W.F., Zhang, M., 2004. Petrogenesis of eastern Nanning Early Yanshanian syenites and granitic complex and its implication. Science in China: Earth Science 34, 493-503.

Cheng, H., Edwards R. L., Hoff J., Gallup C. D., Richards D. A. and Asmerom Y.., 2000. The half-lives of uranium-234 and thorium-230. Chemical Geology, 169, 17-33.

Claude, C., Meunier, J.-D., Chabaux, F., Dussouillez, P., Pelt, E., Hamelin, B., Traoré, D., Colin, F., 2016. Timescale of spheroidal weathering of a $293 \mathrm{kyr}$-old basaltic lava from Réunion Island, Indian Ocean. Chemical Geology 446, 110-125.

Cogez, A., Herman, F., Pelt, E., Reuschle, T., Morvan, G., Darvill, C.M., Norton, K.P., Christl, M., Marki, L., Chabaux, F., 2018. U-Th and Be-10 constraints on sediment recycling in proglacial settings, Lago Buenos Aires, Patagonia. Earth Surface Dynamics 6, 121-140.

Cui, L.-F., Liu, C.-Q., Xu, S., Zhao, Z.-Q., Liu, T.-Z., Liu, W.-J., Zhang, Z.-J., 2016. Subtropical denudation rates of granitic regolith along a hill ridge in Longnan, SE China derived from cosmogenic nuclide depth-profiles. Journal of Asian Earth Sciences 117, 146-152.

Dequincey, O., Chabaux, F., Clauer, N., Sigmarsson, O., Liewig, N., Leprun, J.C., 2002. Chemical mobilizations in laterites: evidence from trace elements and $238 \mathrm{U}-234 \mathrm{U}-230$ Th disequilibria. Geochimica et Cosmochimica Acta 66, 1197-1210.

Dixon, J.L., von Blanckenburg, F., 2012. Soils as pacemakers and limiters of global silicate weathering. Comptes Rendus Geoscience 344, 597-609.

Dosseto, A., Bourdon, B., Gaillardet, J., Mauricebourgoin, L., Allegre, C., 2006a. Weathering and transport of sediments in the Bolivian Andes: Time constraints from uranium-series isotopes. Earth and Planetary Science Letters 248, 759-771.

Dosseto, A., Bourdon, B., Turner, S.P., 2008a. Uranium-series isotopes in river materials: Insights into the timescales of erosion and sediment transport. Earth and Planetary Science Letters 265, 1-17.

Dosseto, A., Buss, H.L., Suresh, P.O., 2012. Rapid regolith formation over volcanic bedrock and 
implications for landscape evolution. Earth and Planetary Science Letters 337-338, 47-55.

Dosseto, A., Turner, S., Douglas, G., 2006b. Uranium-series isotopes in colloids and suspended sediments: Timescale for sediment production and transport in the Murray-Darling River system. Earth and Planetary Science Letters 246, 418-431.

Dosseto, A., Turner, S.P., Chappell, J., 2008b. The evolution of weathering profiles through time: New insights from uranium-series isotopes. Earth and Planetary Science Letters 274, 359-371.

Dosseto, A., Menozzi, D., Kinsley, L.P.J. (2019) Age and rate of weathering determined using uraniumseries isotopes: Testing various approaches. Geochim. Cosmochim. Acta 246, 213-233.

Edmond, J.M., Palmer, M.R., Measures, C.I., Grant, B., Stallard, R.F., 1995. The fluvial geochemistry and denudation rate of the Guayana Shield in Venezuela, Colombia, and Brazil. Geochimica et Cosmochimica Acta 59, 3301-3325.

Engel, J.M., Ma, L., Sak, P.B., Gaillardet, J., Ren, M., Engle, M.A., Brantley, S.L., 2016. Quantifying chemical weathering rates along a precipitation gradient on Basse-Terre Island, French Guadeloupe: New insight from U-series isotopes in weathering rinds. Geochimica et Cosmochimica Acta 195, 29-67.

Fan, C.F., Chen, P.R., 2000. Nd and Sr isotopic compositions of Pitou granitiod in south Jiangxi Province Conributions to Geology \& Mineral Resources Research.

Faure, M., Chen, Y., Feng, Z., Shu, L., Xu, Z., 2017. Tectonics and geodynamics of South China: An introductory note. Journal of Asian Earth Sciences 141, 1-6.

Gontier, A., Rihs, S., Chabaux, F., Lemarchand, D., Pelt, E., Turpault, M.-P., 2015. Lack of bedrock grain size influence on the soil production rate. Geochimica et Cosmochimica Acta 166, 146-164.

Granet, M., Chabaux, F., Stille, P., France-Lanord, C., Pelt, E., 2007. Time-scales of sedimentary transfer and weathering processes from U-series nuclides: Clues from the Himalayan rivers. Earth and Planetary Science Letters 261, 389-406.

Granger, E.G., N. A. Lifton, J.K. Willenbring, 2013. A cosmic trip: 25 years of cosmogenic nuclides in geology. Geological Society of America Bulletin, 125(9-10):1379-1402, DOI: 10.1130/B30774.1

Heisinger B, Lal D, Jull A, Kubik P, Ivy-Ochs S, Knie K, Nolte E. 2002a. Production of selected cosmogenic radionuclides by muons: 2. Capture of negative muons. Earth Planet. Sci. Lett.200: 357-369, doi: 10.1016/S0012-821X(02)00641-6.

Heisinger B, Lal D, Jull A, Kubik P, Ivy-Ochs S, Neumaier S, Knie K, Lazarev V, Nolte E. 2002 b. Production of selected cosmogenic radionuclides by muons: 1. Fast muons. Earth Planet. Sci. Lett.200: 345-355, doi: 10.1016/S0012-821X(02)00640-4.

Jaffey, A.H., Flynn, K.F., Glendenin, L.E., Bentley, W.C., Essling, A.M., 1971. Precision measurement of half-lives and specific activities of 235U and 238U. Phys. Rev. C 4, 1889-1906.

Lal, D., 1991. Cosmic ray labeling of erosion surfaces: in situ nuclide production rates and erosion models. Earth and Planetary Science Letters 104, 424-439.

Lisiecki, L.E., Raymo, M.E., 2005. A Pliocene-Pleistocene stack of 57 globally distributed benthic delta O-18 records. Paleoceanography 20, 17.

Liu, W., Liu, C., Brantley, S.L., Xu, Z., Zhao, T., Liu, T., Yu, C., Xue, D., Zhao, Z., Cui, L.J.C.G., 2016. Deep weathering along a granite ridgeline in a subtropical climate. 427, 17-34.

Lupker, M., Hippe, K., Wacker, L., Kober, F., Maden, C., Braucher, R., Bourles, D., Vidal Romani, J., \& Wieler, R., 2015. Depth-dependence of the production rate of in-situ ${ }^{14} \mathrm{C}$ in quartz from the Leymon High core, Spain. Quaternary Geochronology, 28 , 80-87.

Ma, L., Chabaux, F., Pelt, E., Granet, M., Sak, P.B., Gaillardet, J., Lebedeva, M., Brantley, S.L., 2012. 
The effect of curvature on weathering rind formation: Evidence from Uranium-series isotopes in basaltic andesite weathering clasts in Guadeloupe. Geochimica et Cosmochimica Acta 80, 92-107.

Ma, L., Chabaux, F., West, N., Kirby, E., Jin, L., Brantley, S., 2013. Regolith production and transport in the Susquehanna Shale Hills Critical Zone Observatory, Part 1: Insights from U-series isotopes. Journal of Geophysical Research: Earth Surface 118, 722-740.

Ma, L., Dosseto, A., Gaillardet, J., Sak, P.B. and Brantley, S. (2019) Quantifying weathering rind formation rates using in situ measurements of U-series isotopes with laser ablation and inductively coupled plasma-mass spectrometry. Geochim. Cosmochim. Acta 247, 1-26.

Mathieu, D., Bernat, M., Nahon, D., 1995. Short-lived U and Th isotope distribution in a tropical laterite derived from granite (Pitinga river basin, Amazonia, Brazil): Application to assessment of weathering rate. Earth and Planetary Science Letters 136, 703-714.

Matthews K.A., Murrell M.T., Goldstein S.J., Nunn A.J.and Norman D.E. (2010) Uranium and thorium concentration and isotopic composition in five glass (BHVO-2G, BCR-2G, NKT-1G, T1-G, ATHO-G) and two powder (BHVO-2, BCR-2) reference materials. Geostandards and Geoanalytical Research,35, 227-234.

Marrero, S. M. , Phillips, F. M. , Borchers, B. , Lifton, N. , \& Balco, G. . (2015). Cosmogenic nuclide systematics and the cronuscalc program. Quaternary Geochronology, 31, 160-187.

Navarre-Sitchler, A., Brantley, S., 2007. Basalt weathering across scales. Earth and Planetary Science Letters 261, 321-334.

Owens, P., Slaymaker, O., 2014. An introduction to mountain geomorphology, Mountain geomorphology. Routledge, pp. 9-36.

Pavich, M.J., Leo, G.W., Obermeier, S.F., Estabrook, J.R., 1989. Investigations of the characteristics, origin, and residence time of the upland residual mantle of the Piedmont of Fairfax County, Virginia.

Pelt, E., Chabaux, F., Innocent, C., Navarre-Sitchler, A.K., Sak, P.B., Brantley, S.L., 2008. Uraniumthorium chronometry of weathering rinds: Rock alteration rate and paleo-isotopic record of weathering fluids. Earth and Planetary Science Letters 276, 98-105.

Pelt E., Chabaux F., Stille P., Innocent C., Ghaleb B., Girard M., Guntzer F., 2013, Atmospheric dust contribution to the budget of U-series nuclides in soils from the Mount Cameroon volcano, Chemical Geology, 341, 147-157.

Richter, S., Alonso, A., De Bolle, W., Kühn, H., Verbruggen, A., Wellum, R., Taylor, P.D.P., 2005. Recertification of a series of uranium isotope reference materials: IRMM-183, IRMM-184, IRMM185, IRMM-186 and IRMM-187. International Journal of Mass Spectrometry 247, 37-39.

Riebe, C.S., Hahm, W.J., Brantley, S.L., 2017. Controls on deep critical zone architecture: a historical review and four testable hypotheses. Earth Surface Processes and Landforms 42, 128-156.

Rihs, S., Gontier, A., Pelt, E., Fries, D., Turpault, M.-P., Chabaux, F., 2016. Behavior of U, Th and Ra isotopes in soils during a land cover change. Chemical Geology 441, 106-123.

Rihs, S., Gontier, A., Voinot, A., Chabaux, F., Pelt, E., Lemarchand, D. and Turpault, M.P., 2020. Field biotite weathering rate determination using U-series disequilibria. Geochim. Cosmochim. Acta 276, 404-420.

Rubin, K.H., 2001. Analysis of ${ }^{232} \mathrm{Th} /{ }^{230} \mathrm{Th}$ in volcanic rocks: a comparison of thermal ionization mass spectrometry and other methodologies. Chem. Geol. 175, 723-750.

Sak, P.B., Murphy, M., Ma, L., Gaillardet, J., Herndon, E.M., Brantley, S.L., Daniel, C., 2018. From unweathered core to regolith in a single weathering andesitic clast: Rates and trends of in situ chemical weathering on a tropical volcanic island (Basse Terre Island, French Guadeloupe). 
Chemical Geology 498, 17-30.

Schoonejans, J., Vanacker, V., Opfergelt, S., Granet, M., Chabaux, F., 2016. Coupling uranium series and $10 \mathrm{Be}$ cosmogenic radionuclides to evaluate steady-state soil thickness in the Betic Cordillera. Chemical Geology 446, 99-109.

Sims, K.W.W., Gill, J.B., Dosseto, A., Hoffmann, D.L., Lundstrom, C.C., Williams, R.W., Ball, L., Tollstrup, D., Turner, S., Prytulak, J., Glessner, J.J.G., Standish, J.J., Elliott, T., 2008. An interlaboratory assessment of the thorium isotopic composition of synthetic and rock reference materials. Geostand. Geoanal. Res. 32, 65-91.

Sun J., Xu W., Feng B., 2004. A global search strategy of quantum-behaved 6particle swarm optimization. Cybernetics and Intelligent Systems, IEEE 7 Conference, vol.1, 111-116, doi: 10.1109/ICCIS.2004.1460396

Vigier, N., Bourdon, B., Turner, S., Allègre, C.J., 2001. Erosion timescales derived from U-decay series measurements in rivers. Earth and Planetary Science Letters 193, 549-563.

Vigier, N., Burton, K.W., Gislason, S.R., Rogers, N.W., Duchene, S., Thomas, L., Hodge, E., Schaefer, B., 2006. The relationship between riverine U-series disequilibria and erosion rates in a basaltic terrain. Earth and Planetary Science Letters 249, 258-273.

Wang, X., Chu, G., Sheng, M., Zhang, S., Li, J., Chen, Y., Tang, L., Su, Y., Pei, J., Yang, Z., 2016. Millennial-scale Asian summer monsoon variations in South China since the last deglaciation. Earth and Planetary Science Letters 451, 22-30.

Weyer, S., Anbar,A.D., Gerdes,A., Gordon,G.W., Algeo,T.J., Boyle, E.J., (2008) Natural fractionation of 238U/235U, Geochimica et Cosmochimica Acta, 72, 345-359.

Yang, Y., Liu, C.-Q., Van der Woerd, J., Xu, S., Cui, L.-F., Zhao, Z.-Q., Wang, Q.-L., Jia, G.-D., Chabaux, F., 2019. New constraints on the late Quaternary landscape evolution of the eastern Tibetan Plateau from 10Be and 26Al in-situ cosmogenic nuclides. Quaternary Science Reviews 220, 244-262.

Yang, Y., Lang, Y.-C., Xu, S., Liu, C.-Q., Cui, L.-F., Freeman, S., Wilcken, K.M., 2020. Combined unsteady denudation and climatic gradient factors constrain carbonate landscape evolution: New insights from in situ cosmogenic 36Cl. Quaternary Geochronology 58, 1-11, doi: 10.1016/j.quageo.2020.101075.

Zhang, Z.-J., Liu, C.-Q., Zhao, Z.-Q., Cui, L.-F., Liu, W.-J., Liu, T.-Z., Liu, B.-J., Fan, B.-L., 2015. Behavior of redox-sensitive elements during weathering of granite in subtropical area using X-ray absorption fine structure spectroscopy. Journal of Asian Earth Sciences 105, 418-429. 


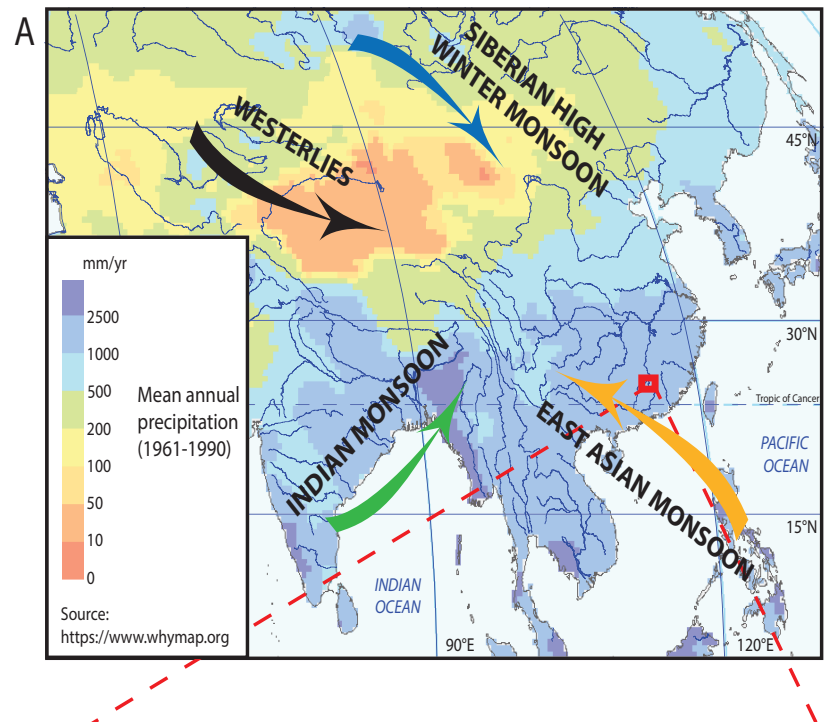

B
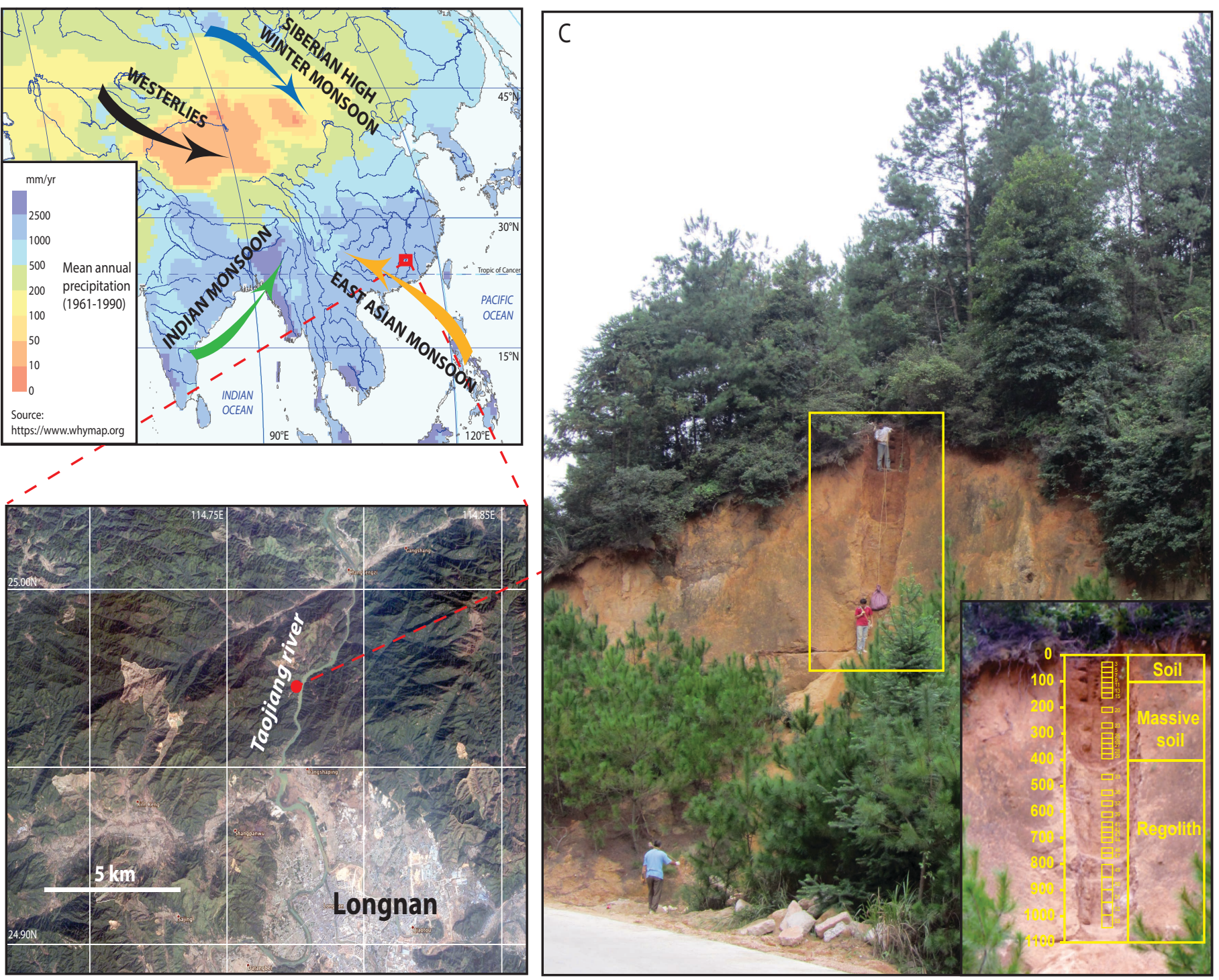

Figure 1 


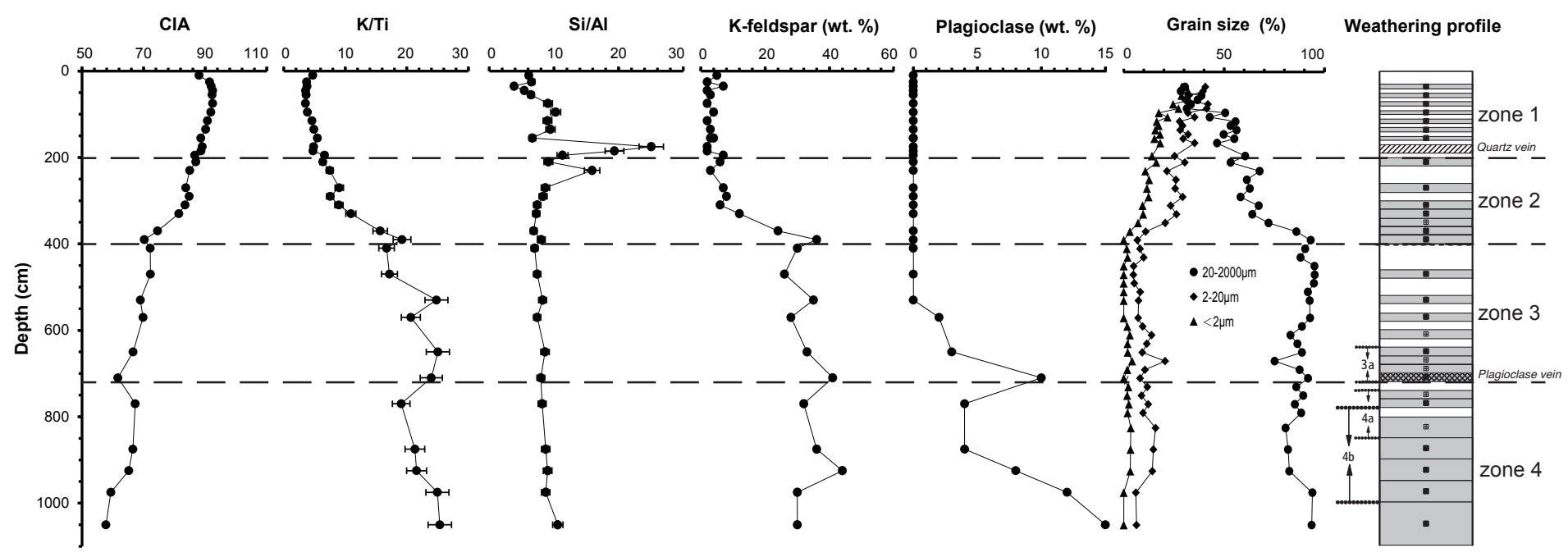

Figure 2 


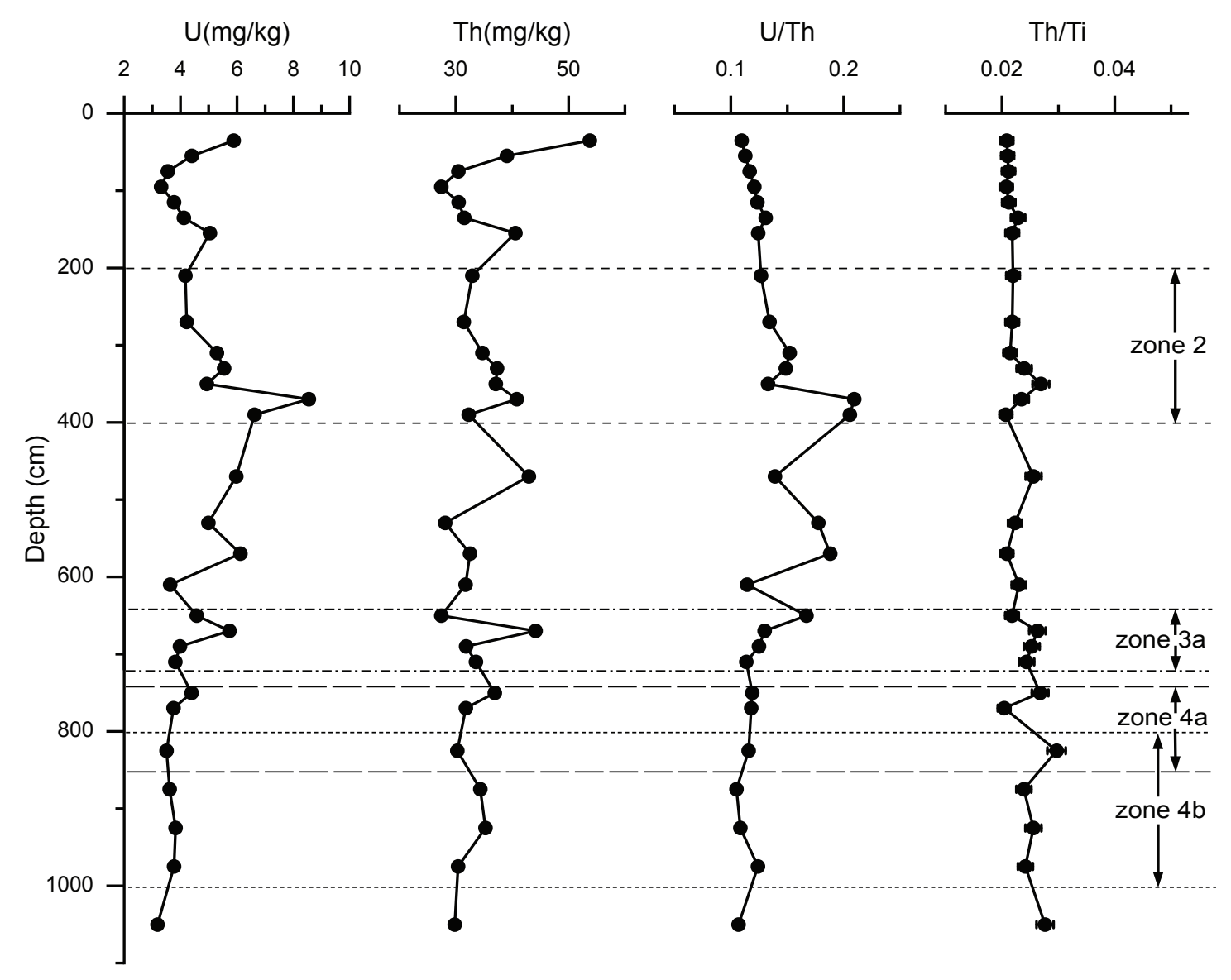

Figure 3 


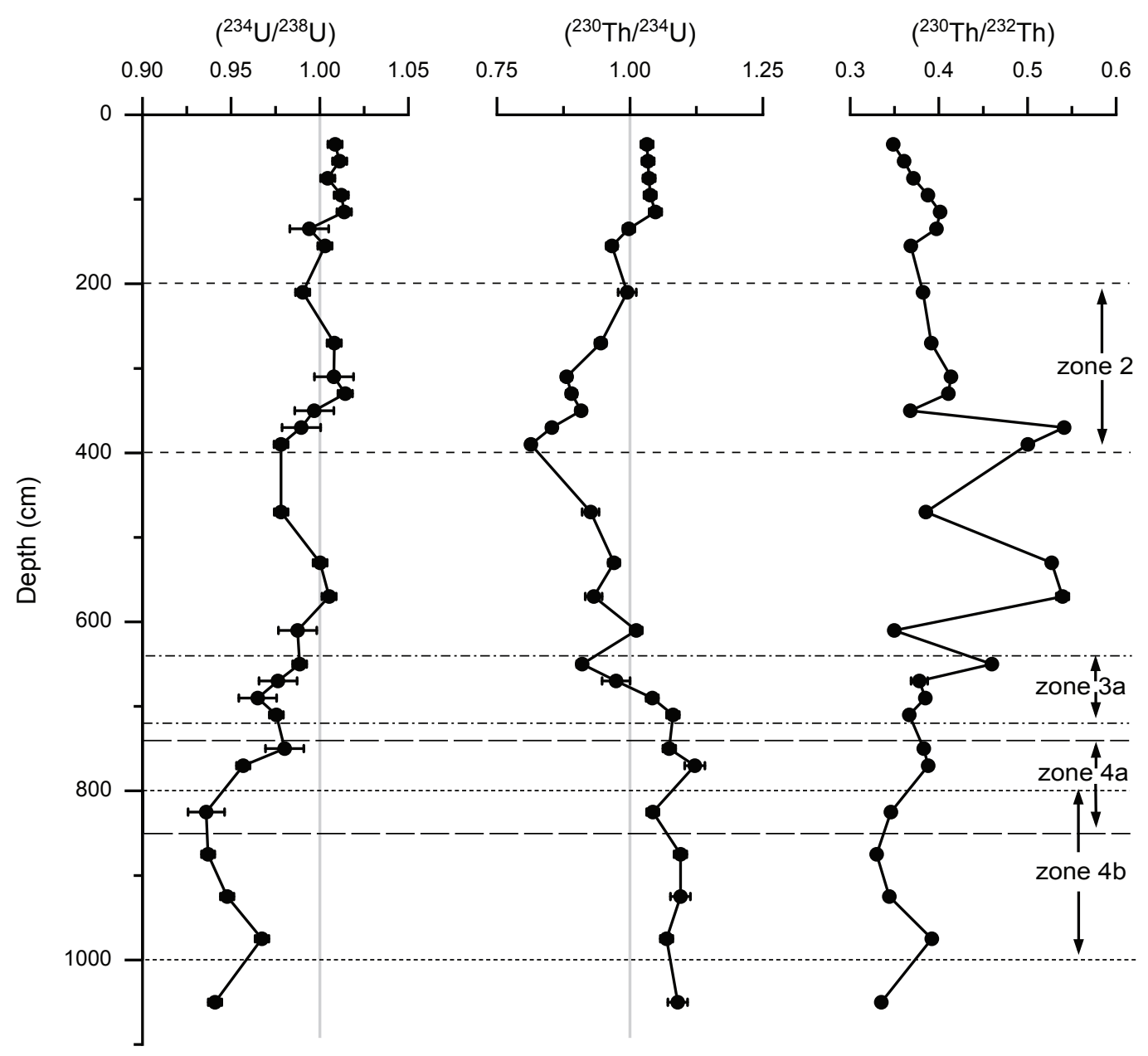

Figure 4 


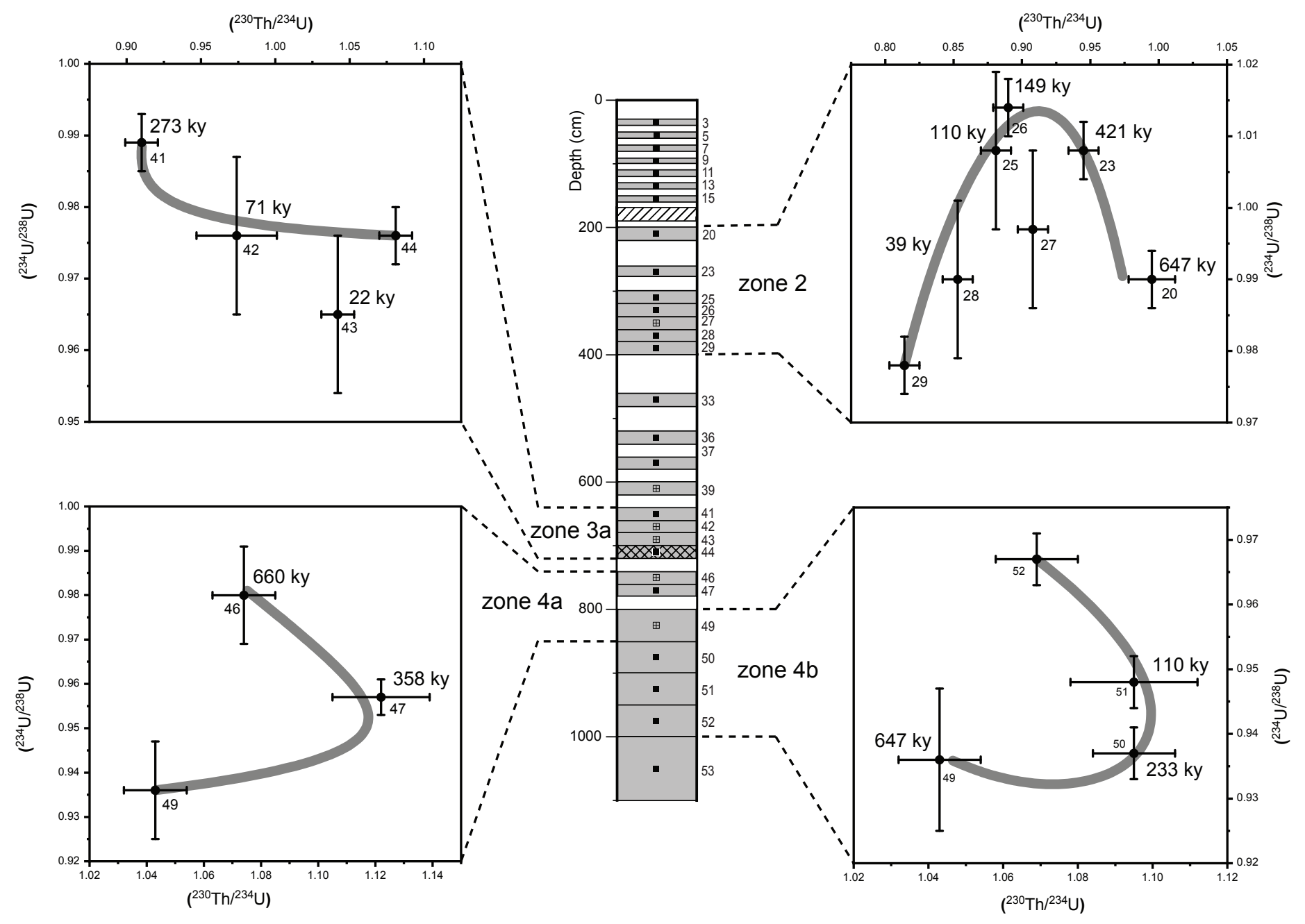

Figure 5 


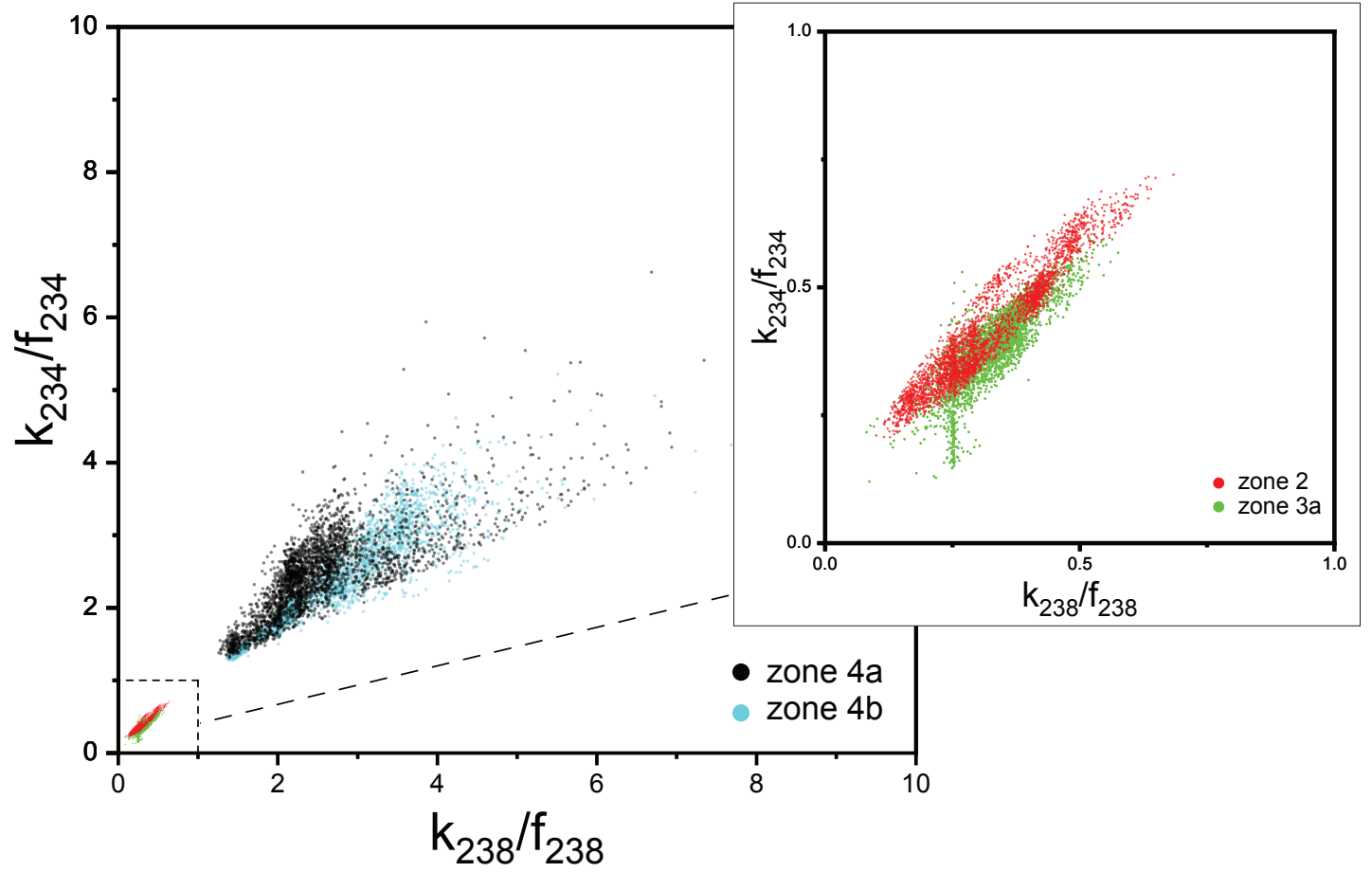

Figure 6 
A

${ }^{10} \mathrm{Be}$ concentration $\left(\times 10^{4}\right.$ atoms $\left./ \mathrm{g}\right)$

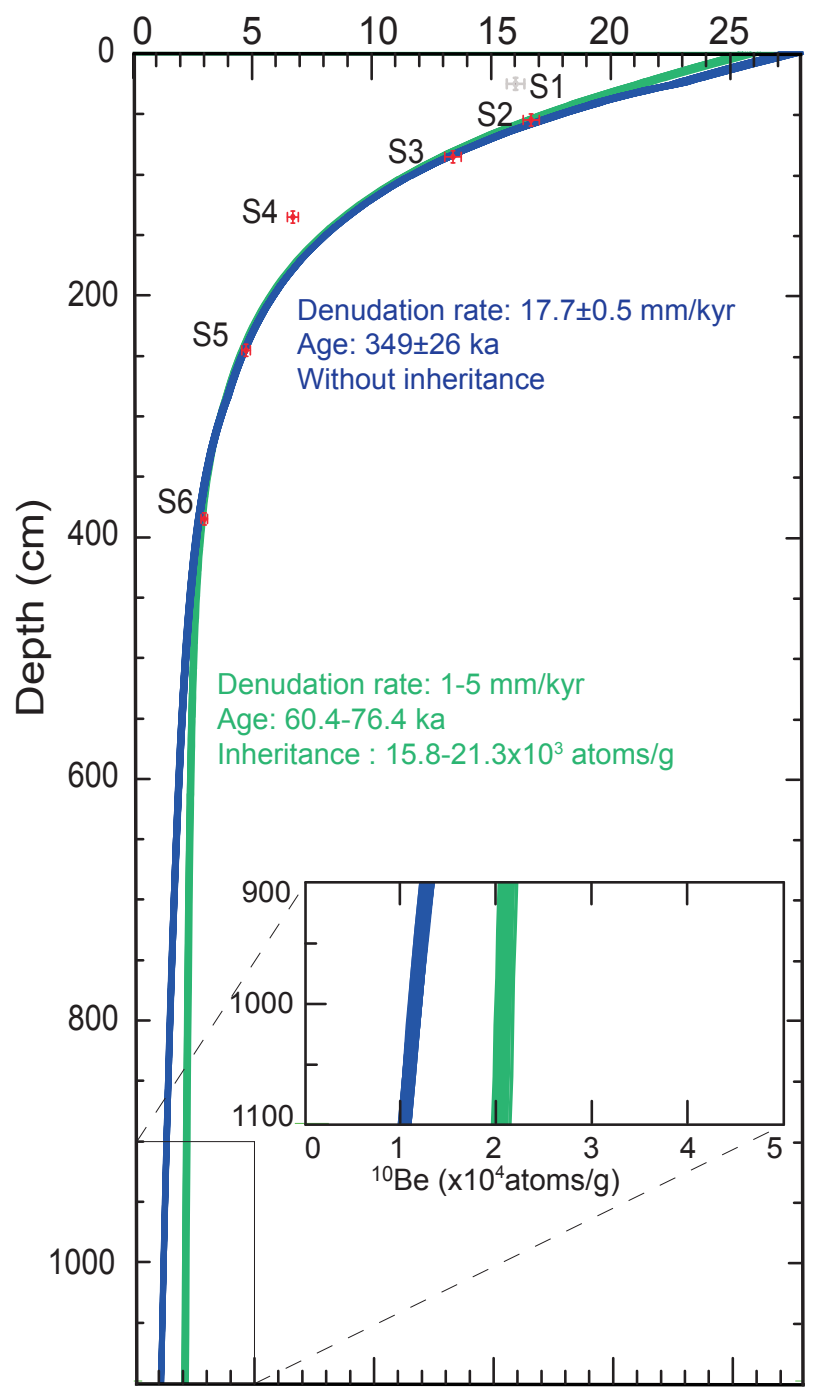

B Production and denudation rates ( $\mathrm{m} / \mathrm{Ma}$ )

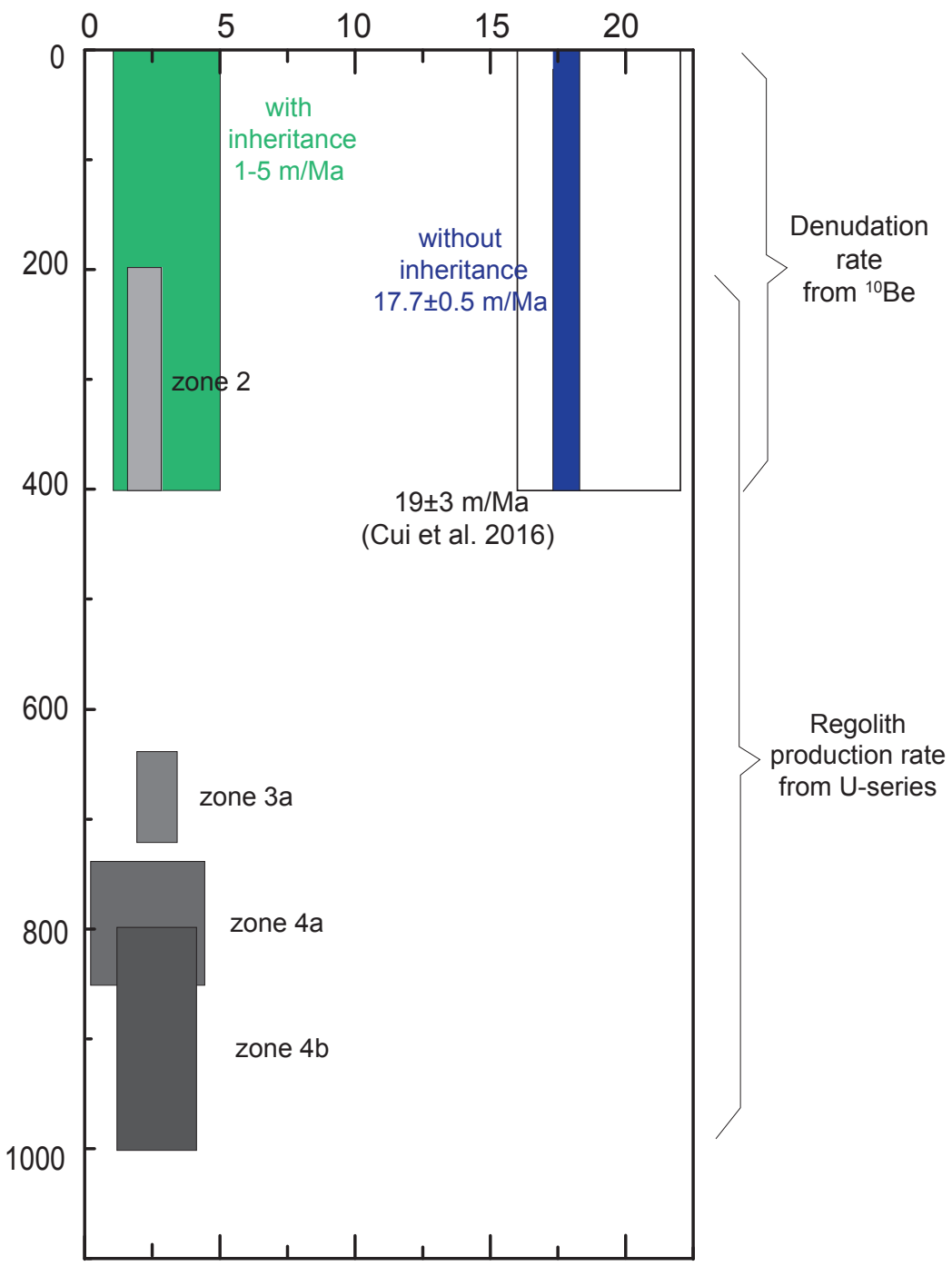




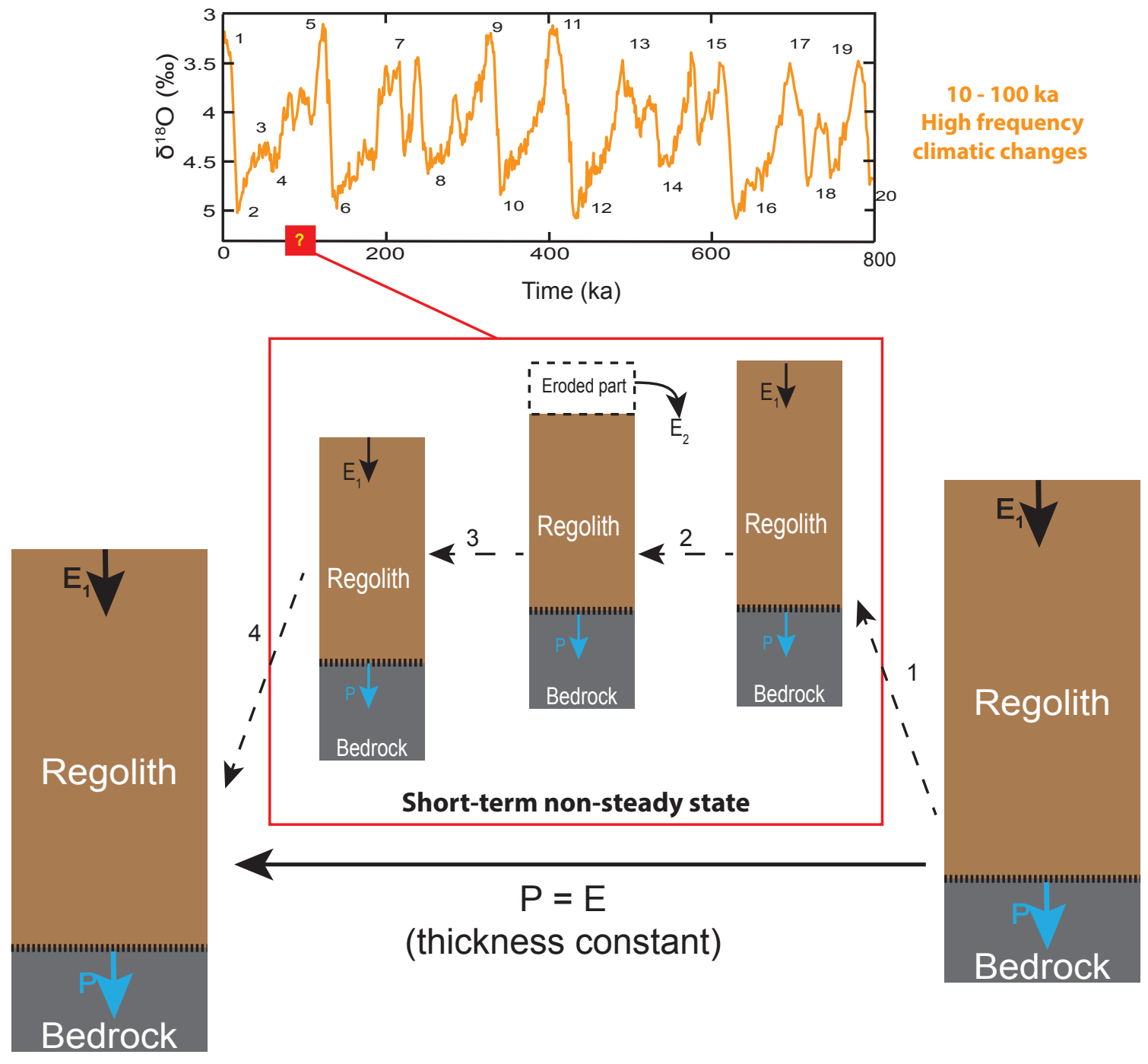

\section{Long-term apparent steady-state}

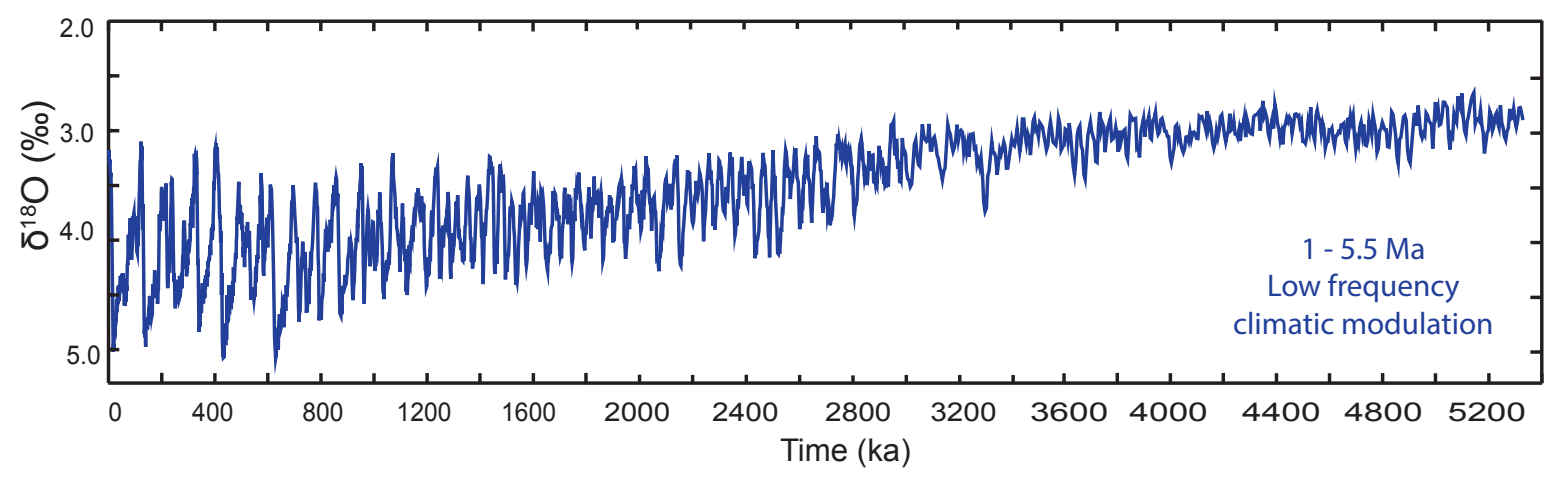

Figure 8 
Table 1: $\mathrm{U}$, Th concentrations and $\left({ }^{234} \mathrm{U} /{ }^{238} \mathrm{U}\right),\left({ }^{230} \mathrm{Th} /{ }^{234} \mathrm{U}\right),\left({ }^{230} \mathrm{Th} /{ }^{232} \mathrm{Th}\right)$ activity ratios

\begin{tabular}{|c|c|c|c|c|c|c|c|c|c|c|}
\hline $\begin{array}{l}\text { JLN-S1 } \\
\text { Sample } \\
\text { Number }\end{array}$ & $\begin{array}{l}\text { Depth } \\
(\mathrm{cm})\end{array}$ & $\begin{array}{c}\mathrm{TiO}_{2} \\
(\mathrm{wt} \%)\end{array}$ & $\begin{array}{c}{[\mathrm{U}]} \\
(\mathrm{mg} / \mathrm{kg}) \\
\pm 2 \% \\
(2 \sigma)\end{array}$ & $\begin{array}{c}{[\mathrm{Th}]} \\
(\mathrm{mg} / \mathrm{kg}) \\
\pm 1.3 \% \\
(2 \sigma)\end{array}$ & $\left({ }^{234} \mathrm{U} /{ }^{238} \mathrm{U}\right)$ & $\pm 2 \sigma$ & $\left({ }^{230} \mathrm{Th} /{ }^{234} \mathrm{U}\right)$ & $\pm 2 \sigma$ & $\left({ }^{230} \mathrm{Th} /{ }^{232} \mathrm{Th}\right)$ & $\pm 2 \sigma$ \\
\hline 03 & $30-40$ & 0.43 & 5.89 & $\begin{array}{l}53.8 \\
\end{array}$ & 1.009 & 0.004 & 1.032 & 0.011 & 0.349 & 0.003 \\
\hline 05 & $50-60$ & 0.31 & 4.40 & 39.0 & 1.011 & 0.004 & 1.034 & 0.011 & 0.361 & 0.004 \\
\hline 07 & $70-80$ & 0.24 & 3.55 & 30.5 & 1.005 & 0.004 & 1.036 & 0.011 & 0.371 & 0.004 \\
\hline 09 & $90-100$ & 0.22 & 3.31 & 27.4 & 1.012 & 0.004 & 1.038 & 0.011 & 0.388 & 0.004 \\
\hline 11 & $110-120$ & 0.24 & 3.77 & 30.5 & 1.014 & 0.004 & 1.048 & 0.012 & 0.401 & 0.004 \\
\hline 13 & $130-140$ & 0.23 & 4.12 & 31.5 & 0.994 & 0.011 & 0.998 & 0.011 & 0.397 & 0.004 \\
\hline 15 & $150-160$ & 0.31 & 5.04 & 40.6 & 1.003 & 0.004 & 0.966 & 0.011 & 0.368 & 0.004 \\
\hline 20 & $200-220$ & 0.25 & 4.17 & 32.9 & 0.990 & 0.004 & 0.995 & 0.017 & 0.382 & 0.005 \\
\hline 23 & $260-280$ & 0.24 & 4.22 & 31.4 & 1.008 & 0.004 & 0.945 & 0.010 & 0.392 & 0.004 \\
\hline 25 & $300-320$ & 0.27 & 5.29 & 34.7 & 1.008 & 0.011 & 0.881 & 0.010 & 0.414 & 0.004 \\
\hline 26 & $320-340$ & 0.26 & 5.55 & 37.3 & 1.014 & 0.004 & 0.890 & 0.010 & 0.411 & 0.004 \\
\hline 27 & $340-360$ & $0.23^{*}$ & 4.93 & 37.1 & 0.997 & 0.011 & 0.908 & 0.010 & 0.368 & 0.004 \\
\hline 28 & $360-380$ & 0.29 & 8.55 & 40.8 & 0.990 & 0.011 & 0.853 & 0.009 & 0.541 & 0.005 \\
\hline 29 & $380-400$ & 0.26 & 6.63 & 32.3 & 0.978 & 0.004 & 0.814 & 0.009 & 0.500 & 0.005 \\
\hline 33 & $460-480$ & 0.28 & 5.98 & 43.0 & 0.978 & 0.004 & 0.926 & 0.016 & 0.385 & 0.005 \\
\hline 36 & $520-560$ & 0.21 & 4.99 & 28.1 & 1.000 & 0.004 & 0.970 & 0.011 & 0.527 & 0.005 \\
\hline 37 & $560-580$ & 0.26 & 6.12 & 32.5 & 1.005 & 0.004 & 0.932 & 0.016 & 0.540 & 0.007 \\
\hline 39 & $600-620$ & $0.23^{*}$ & 3.63 & 31.7 & 0.988 & 0.011 & 1.012 & 0.011 & 0.350 & 0.004 \\
\hline 41 & $640-660$ & 0.21 & 4.58 & 27.4 & 0.989 & 0.004 & 0.910 & 0.010 & 0.460 & 0.005 \\
\hline 42 & $660-680$ & $0.28^{*}$ & 5.74 & 44.2 & 0.976 & 0.011 & 0.974 & 0.026 & 0.378 & 0.009 \\
\hline 43 & $680-700$ & $0.21^{*}$ & 3.98 & 31.8 & 0.965 & 0.011 & 1.042 & 0.011 & 0.385 & 0.004 \\
\hline 44 & $700-720$ & 0.23 & 3.82 & 33.6 & 0.976 & 0.004 & 1.081 & 0.012 & 0.367 & 0.004 \\
\hline 46 & $740-760$ & $0.23 *$ & 4.39 & 36.9 & 0.980 & 0.011 & 1.074 & 0.012 & 0.383 & 0.004 \\
\hline 47 & $760-780$ & 0.26 & 3.75 & 31.8 & 0.957 & 0.004 & 1.122 & 0.019 & 0.388 & 0.005 \\
\hline 49 & $800-850$ & $0.17^{*}$ & 3.50 & 30.3 & 0.936 & 0.010 & 1.043 & 0.011 & 0.346 & 0.003 \\
\hline 50 & $850-900$ & 0.24 & 3.61 & 34.4 & 0.937 & 0.004 & 1.095 & 0.012 & 0.330 & 0.003 \\
\hline 51 & 900-950 & 0.23 & 3.82 & 35.3 & 0.948 & 0.004 & 1.095 & 0.019 & 0.344 & 0.004 \\
\hline 52 & $950-1000$ & 0.21 & 3.77 & 30.4 & 0.967 & 0.004 & 1.069 & 0.012 & 0.392 & 0.004 \\
\hline 53 & $1000-1100$ & 0.18 & 3.19 & 29.8 & 0.941 & 0.004 & 1.090 & 0.019 & 0.335 & 0.004 \\
\hline
\end{tabular}

Uranium concentrations and activity ratios were calculated assuming an isotopic ${ }^{238} \mathrm{U} / 235 \mathrm{U}$ ratio of 137.83 (Weyer et al., 2008) and decay constants $\lambda_{238}$ and $\lambda_{234}$ of $1.551 \times 10^{-10} \mathrm{yr}^{-1}$ and $2.826 \times 10^{-6} \mathrm{yr}^{-1}$, respectively (Jaffey et al., 1971; Cheng et al., 2000), and $\lambda_{230}$ and $\lambda_{232}$ of $9.158 \times 10^{-6} \mathrm{yr}^{-1}$ and of $4.932 \times 10^{-11} \mathrm{yr}^{-1}$, respectively (Cheng et al., 2000; Rubin, 2001). Analytical uncertainties $( \pm 2 \sigma)$ were estimated from the 2SD-reproducibility observed for all the sample powder duplicates $(n=7)$ and the rock standard replicates $(\mathrm{n}=4)$. For some measurements this global estimation was adjusted to account for the internal error of the measurement or to the result of the rock standard of the session. $\mathrm{TiO}_{2}$ (weight percent) concentrations are from Liu et al. (2016) and Zhang et al. (2015) except $(*)$, which has been analyzed for this study at the China University of Geosciences (Wuhan) following the approach given in Zhang et al. (2015). Precision on Ti concentrations are estimated to be $\pm 2 \%$. 
Table 2: Production rates and mobility parameters (ki, fi) obtained for zones 2, 3a, 4a, and $4 \mathrm{~b}$ (see text for details).

\begin{tabular}{|c|c|c|c|c|c|c|c|c|c|c|}
\hline Zone & Var. & $\mathrm{P}(\mathrm{m} / \mathrm{Ma})$ & $\mathrm{k}_{238}\left(\mathrm{y}^{-1}\right)$ & $\mathrm{f}_{238}\left(\mathrm{y}^{-1}\right)$ & $\mathrm{k}_{234}\left(\mathrm{y}^{-1}\right)$ & $\mathrm{f}_{234}\left(\mathrm{y}^{-1}\right)$ & $\mathrm{k}_{234} / \mathrm{k}_{238}$ & $\mathrm{f}_{234} / \mathrm{f}_{238}$ & $\mathrm{k}_{238} / \mathrm{f}_{238}$ & $\mathrm{k}_{234} / \mathrm{f}_{234}$ \\
\hline \multirow[t]{2}{*}{ Zone 2} & mean & 2.21 & 5.37 E-07 & 17.4 E-07 & $9.60 \mathrm{E}-07$ & 24.9 E-07 & 1.98 & 1.44 & 0.32 & 0.42 \\
\hline & Std dev. & 0.21 & 1.94 E-07 & 2.3 E-07 & 2.94 E-07 & 3.15 E-07 & 0.40 & 0.14 & 0.11 & 0.11 \\
\hline \multirow[t]{2}{*}{ Zone 3a } & mean & 2.66 & 8.79 E-07 & 40.6 E-07 & 9.14 E-07 & 23.6 E-07 & 1.35 & 1.15 & 0.33 & 0.38 \\
\hline & Std dev. & 0.23 & 1.70 E-07 & $2.24 \mathrm{E}-07$ & 2.34 E-07 & 3.10 E-07 & 0.26 & 0.11 & 0.07 & 0.07 \\
\hline \multirow[t]{2}{*}{ Zone $4 \mathrm{a}$} & mean & 1.85 & 24.2 E-07 & 9.92 E-07 & 30.5 E-07 & 14.3 E-07 & 1.29 & 1.51 & 2.54 & 2.22 \\
\hline & Std dev. & 0.59 & 11.4 E-07 & 7.81 E-07 & 16.3 E-07 & $11.3 \mathrm{E}-07$ & 0.14 & 0.26 & 0.84 & 0.68 \\
\hline \multirow[t]{2}{*}{ Zone $4 \mathrm{~b}$} & Mean & 2.33 & 12.4 E-07 & 5.23 E-07 & $17.9 \mathrm{E}-07$ & $7.21 \mathrm{E}-07$ & 1.52 & 1.61 & 2.38 & 2.44 \\
\hline & Std dev. & 0.23 & 2.73 E-07 & 2.00 E-07 & 3.11 E-07 & 2.42 E-07 & 0.30 & 0.56 & 0.47 & 0.50 \\
\hline
\end{tabular}

